\title{
Populációdinamikai rendszerek elméleti és számítógépes stabilitásvizsgálata
}

\author{
Doktori értekezés
}

\author{
DÉnes AtTila \\ Témavezető: \\ Dr. HATVANI LÁSZLÓ \\ Matematika- és Számítástudományok Doktori Iskola \\ Szegedi Tudományegyetem \\ Természettudományi és Informatikai Kar \\ Bolyai Intézet
}

2011

Szeged 


\section{Tartalomjegyzék}

1. Bevezetés 1

1.1. A dolgozat felépítése és tartalma . . . . . . . . . . . 2

2. Dinamikus rendszerek $\quad 5$

3. A Tusnády-modell 9

3.1. A Tusnády-modell . . . . . . . . . . . . . . . . . . . . . 9

3.2. A 3.5. tétel bizonyítása . . . . . . . . . . . . . . . . . . 19

4. Dinamikus rendszerek attraktorainak számítógépes vizsgá$\begin{array}{ll}\text { lata } & 30\end{array}$

4.1. A Dynamics algoritmusa . . . . . . . . . . . . . . . . 31

4.2. Az új algoritmus . . . . . . . . . . . . . . . . . . 32

4.3. A program . . . . . . . . . . . . . . . 35

4.4. Példák . . . . . . . . . . . . . . . . . . 35

4.4.1. Az Hénon-leképezés . . . . . . . . . . . . . . . . 35

4.4.2. A Bogdanov-leképezés . . . . . . . . . . . 36

4.4.3. Háromdimenziós Tinkerbell-leképezés . . . . . . . . . 38

4.4.4. Diszkrét ragadozó-zsákmány modell (Maynard Smith) 39 
5. Egy nemautonóm populációdinamikai modell eventuális stabilitási tulajdonságai

5.1. A modell . . . . . . . . . . . . . . . . . . . . . . . . 40

5.2. A modell egyszerüsítése . . . . . . . . . . . . . . . . . . . . 42

5.3. A stabilitási tétel . . . . . . . . . . . . . . . . . 46

5.4. Bevezető jelölések és lemmák . . . . . . . . . . . . . . . 48

5.5. Az 5.5. tétel bizonyítása . . . . . . . . . . . . . . . . 54

5.6. A modell módosítása . . . . . . . . . . . . . . . . . . . 61

$\begin{array}{lc}\text { Összefoglalás } & 63\end{array}$

$\begin{array}{ll}\text { Summary } & 68\end{array}$

$\begin{array}{ll}\text { Köszönetnyilvánítás } & 73\end{array}$

$\begin{array}{ll}\text { Tárgymutató } & 74\end{array}$

$\begin{array}{ll}\text { Irodalomjegyzék } & 76\end{array}$ 


\section{Ábrák jegyzéke}

3.1. A mutáció típusai . . . . . . . . . . . . . . . . . . . . 10

3.2. A rekombináció típusai . . . . . . . . . . . . . . . . 11

3.3. A Tusnády-rendszer torlódási pontjainak halmaza . . . . . . . 14

3.4. Szuperkritikus Neimark-Sacker-bifurkáció . . . . . . . . . . 16

3.5. Szubkritikus Neimar-Sacker-bifurkáció . . . . . . . . . . . . 17

3.6. A Tusnády-rendszer attraktora $p=8$ paraméterértéknél . . . . 18

3.7. A Tusnády-rendszer attraktora $p=135$ paraméterértéknél . . 18

3.8. A Tusnády-rendszer dinamikája . . . . . . . . . . . . . . . . . 19

3.9. r interpolációs függvénye . . . . . . . . . . . . 27

4.1. Az Hénon-leképezés . . . . . . . . . . . . . . . . . . . . 36

4.2. A Bogdanov-leképezés . . . . . . . . . . . . . . 37

4.3. A Bogdanov-leképezés (Dynamics) . . . . . . . . . . 37

4.4. Háromdimenziós Tinkerbell-leképezés . . . . . . . . . . . . . . 38

4.5. Maynard Smith ragadozó-zsákmány modellje . . . . . . . . . . 39

5.1. Eventuális egyenletes stabilitás . . . . . . . . . . . . 54

5.2. Trajektória és határhalmaza . . . . . . . . . . . . . 55

5.3. A $H_{1}, \ldots, H_{4}$ halmazok . . . . . . . . . . . . . . . . . . 56

5.4. (5.22) egy pályájának képe Mathematicá-val . . . . . . . 61 


\section{1. fejezet}

\section{Bevezetés}

A populációdinamika biológiai populációk méretének és összetételének időbeli változását modellezi. A tudományterület gyökerei nagyon régre nyúlnak vissza: az egyik legkorábbi populációdinamikai témájú munkának tekinthetjük Fibonacci 1202-es modelljét, amelyben egy nyúlpopuláció növekedését vizsgálja.

Daniel Bernoulli a XVIII. század közepén differenciálegyenletes modellt állított fel a himlő terjedésének vizsgálatára, amelyet később d’Alembert fejlesztett tovább.

Pierre François Verhulst belga matematikus 1838-ban publikálta a népesség növekedésének modellezésére az $\dot{N}=r N(1-N / K)$ ún. logisztikus egyenletet, ahol $K$ a környezet eltartóképessége. Ha a populáció mérete jóval kisebb a környezet eltartóképességénél, akkor a populáció gyakorlatilag exponenciálisan nő, majd egyre lassuló növekedéssel tart a környezet eltartóképességéhez.

Az 1920-as években Vito Volterra olyan modellt keresett, amely megmagyarázza, hogy az I. világháború idején lecsökkent halászat miért okozta a ragadozó halak arányának növekedését az Adriai-tengerben. Alfred J. Lotka hasonló egyenletet közölt egy növény és egy növényevő állatfaj mennyisége változásának modellezésére. Az általuk felállított Lotka-Volterra-egyenlet az elsố ragadozó-zsákmány modell. 
A populációdinamika azóta is fejlődik, ahogy azt Bacaër monográfiája [2] is mutatja. Ez a fejlődés különösen felgyorsult a számítógépes szimulációk lehetôségének megjelenésével.

A disszertációban két populációdinamikai modell stabilitási és bifurkációs tulajdonságait tanulmányozzuk, illetve ismertetünk egy dinamikus rendszerek attraktorainak számítására szolgáló algoritmust és az algoritmust megvalósító számítógépes programot, amelyet a két modell vizsgálatához alkottunk meg.

Az értekezés a szerzô következô publikációin alapul:

- Dénes, A., Neimark-Sacker bifurcation in a discrete dynamical model of population genetics, Electronic Journal of Qualitative Theory of Differential Equations, Proc. 8th Coll. Qualitative Theory of Diff. Equ., No. 6. (2008), 1-10.

- Dénes, A., Hatvani, L., Stachó, L. L., Eventual stability properties in a non-autonomous model of population dynamics, Nonlinear Analysis 73 (2010) 650-659.

- Dénes, A., Makay, G., Attractors and basins of dynamical systems, Electronic Journal of Qualitative Theory of Differential Equations, No. 20. (2011), 1-11.

\subsection{A dolgozat felépítése és tartalma}

A bevezetést követô második fejezetben néhány alapvetô fogalmat definiálunk a dinamikus rendszerek elméletéból.

A harmadik fejezetben Tusnády Gábor egy populációdinamikai modelljével foglalkozunk. Ez a genetikai modell, amely egy nemlineáris, négy független változót tartalmazó differenciaegyenlet-rendszer, egy populációban az ivarsejtek eloszlásának változását írja le egy lókusz és négy allél esetén a szelekció és a mutáció hatásának figyelembevételével. Tusnády Gábor számítógépes 
kísérletezéssel talált olyan eseteket, amelyekben a rendszer attraktora nem egy pont (vagyis az eloszlások között nem áll be dinamikus egyensúly), hanem periodikus pálya, sôt, valamilyen kaotikus halmaz. Azt kérdezte, hogy ez a jelenség törvényszerú, vagy esetleg csak a numerikus közelítés hibájából adódik. Hatvani László, Toókos Ferenc és Tusnády Gábor [11]-ben megmutatta, hogy a folytonos esetben tapasztalható hasonló jelenség magyarázata egy Hopf-bifurkáció.

Bebizonyítjuk, hogy a jelenség a diszkrét esetben is törvényszerú: belátjuk, hogy a rendszer bizonyos paraméterek változtatásakor Neimark-Sackerbifurkáción megy keresztül.

Ennek a modellnek a vizsgálatához szükségünk volt egy olyan programra, amellyel dinamikus rendszerek attraktorait és azok medencéit lehet kiszámítani és ábrázolni. A korábbi, dinamikus rendszerek vizsgálatára szolgáló programcsomagok azonban általában nem rendelkeznek ilyen eljárással, vagy algoritmusuk pontatlanságokhoz vezethet, illetve a programok régen készültek, így ma már nehezen használhatóak. Ezért szükségünk volt egy új, az eddigieknél pontosabb algoritmusra és az algoritmus alapján készült programra, amelynek segítségével tetszóleges dimenziójú dinamikus rendszer attraktorait tudjuk ábrázolni.

A dolgozatban ismertetjük az új algoritmust és az algoritmus alapján készült programot, és néhány ismert dinamikus rendszer attraktorát bemutató ábrával szemléltetjük a program múködését.

Az ötödik fejezetben egy populációdinamikai modellt vizsgálunk. Ez a modell a Tanganyika-tóban élő két halfaj (egy ragadozó és egy növényevô), valamint a növényevô halak táplálékául szolgáló növényzet mennyiségének változását írja le. A modell két részból áll: év közben egy differenciálegyenlet-rendszer írja le a fejlődést, míg minden év végén egy diszkrét dinamikus rendszer írja le a halak szaporodását.

Az év közbeni fejlődést leíró nemautonóm differenciálegyenlet-rendszernek nincs egyensúlyi helyzete, azonban van határegyenlete, és a határegyenletnek van egyensúlyi helyzete. Ilyen esetben az ún. eventuális stabilitási tulajdon- 
ságokat (eventual stability properties, Yoshizawa [22]) szokták vizsgálni. Fó eredményünk, hogy a nemautonóm rendszer minden megoldása tart a határegyenlet egyensúlyi helyzetéhez, éspedig bizonyos értelemben egyenletes módon. A bizonyítás ötvözi a linearizálás módszerét, a határegyenletek módszerét és Ljapunov direkt módszerét. 


\section{2. fejezet}

\section{Dinamikus rendszerek}

A fizikai, kémiai, biológiai, gazdasági folyamatok jövô- és múltbéli állapotai bizonyos mértékig kiszámíthatók, ha ismerjük jelenlegi állapotukat és a fejlódésüket szabályozó törvényeket. Amennyiben ezek a törvények nem változnak az idóben, az ilyen rendszerek viselkedését teljesen meghatározza kiindulási állapotuk. A dinamikus rendszerek fogalma az ilyen determinisztikus folyamatok matematikai modelljét jelenti. Vagyis a dinamikus rendszer fogalma magában foglalja a lehetséges állapotok halmazát és a fejlődés törvényeit az idő függvényében.

A rendszer minden lehetséges állapotát valamilyen állapottérnek nevezett $X$ halmaz egy pontja jelzi. Egy $x \in X$ pont nem csak a rendszer jelenlegi helyzetét írja le, hanem a fejlődését is meghatározza. Az állapotteret a klasszikus mechanikából eredő hagyományokat követve gyakran fázistérnek is nevezik.

Az állapotok közti átmenetet egy leképezés adja meg, ez előírja, hogy a rendszer valamely állapotból $t$ idố alatt mely állapotba megy át.

Ezek után megadhatjuk a dinamikus rendszer fogalmának pontos definícióját:

2.1. Definíció. Legyen $X \subset \mathbb{R}^{n}$ és $Y \subset \mathbb{R} . A z(X, \pi)$ párt dinamikus rendszernek nevezzük, ha a $\pi: X \times Y \rightarrow X$ leképezés rendelkezik a következó tulajdonságokkal: 
- $\pi(x, 0)=x$ minden $x \in X$ esetén (kezdetiérték-tulajdonság),

- $\pi(\pi(x, t), s)=\pi(x, t+s)$ minden $x \in X$ és $t, s \in Y$ esetén (csoporttulajdonság),

- $\pi$ folytonos az $X \times Y$ szorzattéren.

$X$-et nevezzük állapottérnek, $Y$ pedig az időt jelenti. $Y$ valamilyen számhalmaz, leggyakrabban $Y=\mathbb{R}$ vagy $Y=\mathbb{Z}$. Ha $Y$ a valós számok halmaza, akkor folytonos, ha $Y$ az egészek halmaza, akkor diszkrét dinamikus rendszerrôl beszélünk.

2.2. Definíció. Legyen $x \in X$ tetszóleges. Ekkor a

$$
\xi_{x}: Y \rightarrow X, \quad \xi_{x}: t \mapsto \pi(x, t)
$$

leképezést az $x$ pont orbitális függvényének vagy mozgásának, a $\xi_{x}(Y) \in X$ halmazt pedig az $x$ pont pályájának vagy trajektóriájának nevezzük. Az állapottér pályákra particionálását a dinamikus rendszer fázisképének nevezzük.

$A z x_{0} \in X$ pontot egyensúlyi helyzetnek vagy fixpontnak nevezzük, ha $\pi\left(x_{0}, t\right)=x_{0}$ minden $t \in Y$ esetén. Az elnevezést az indokolja, hogy ezzel a kezdeti értékkel indulva a mozgás állandó, vagyis a trajektória egy pontból áll.

Egy $L_{0}$ pályát periodikusnak nevezünk, ha minden $x_{0} \in L_{0}$ pontra és minden $t \in Y$ esetén $\pi\left(x_{0}, t+T_{0}\right)=\pi\left(x_{0}, t\right)$ teljesül valamilyen $T_{0}>0$-ra.

2.3. Példa. Legyen adott az

$$
x^{\prime}=g(x)
$$

közönséges, autonóm differenciálegyenlet, ahol $g: \mathbb{R}^{n} \rightarrow \mathbb{R}^{n}$ folytonos függvény. Tegyük fel, hogy a rendszer bármely megoldása folytatható a $(-\infty, \infty)$ intervallumon. Jelölje $x\left(\cdot, t_{0}, x_{0}\right): \mathbb{R} \rightarrow \mathbb{R}^{n}$ az $x\left(t_{0}, t_{0}, x_{0}\right)=x_{0}$ feltételnek eleget tevô megoldást. Definiáljuk az $f$ függvényt a következô módon:

$$
f: \mathbb{R}^{n} \times \mathbb{R} \rightarrow \mathbb{R}^{n}
$$




$$
f:(x, t) \mapsto x\left(t_{0}+t, t_{0}, x\right)
$$

Ebben az esetben $f$ egy folytonos dinamikus rendszert határoz meg.

2.4. Példa. Legyen $F: \mathbb{R}^{m} \rightarrow \mathbb{R}^{m}$ folytonos, invertálható leképezés. Az

$$
x_{n+1}=F\left(x_{n}\right)
$$

differenciaegyenlet egy diszkrét dinamikus rendszert definiál: a 2.1. definíció jelöléseit használva:

$$
\pi(x, n)=F^{n}(x)
$$

ahol $F^{n}$ az $F$ leképezés $n$-edik iteráltját jelöli.

Az alábbiakban ismertetjük a kaotikus halmaz, az attraktor, illetve néhány kapcsolódó fogalom definícióját a [24] monográfia felhasználásával.

2.5. Definíció. Legyen $\Lambda$ kompakt részhalmaza $\mathbb{R}^{m}$-nek. A $\Lambda$ halmazt invariánsnak nevezzük a $\pi(x, t)$ dinamikus rendszerre nézve, $h a \pi(\Lambda, t) \subset \Lambda$ minden $t \in Y$ esetén.

2.6. Definíció. Azt mondjuk, hogy a $\pi(x, t)$ dinamikus rendszer érzékenyen függ a kezdeti feltételektôl $\Lambda$ - $n$, ha létezik olyan $\varepsilon>0$, hogy bármely $x \in \Lambda$ hoz és $x$ bármely $U$ környezetéhez megadható olyan $y \in U$ és $t>0$, amelyre $|\pi(x, t)-\pi(y, t)|>\varepsilon$.

2.7. Definíció. Egy invariáns zárt A halmazt topologikusan tranzitívnak nevezünk, ha bármely $U, V \subset A$ részhalmazokra létezik olyan $t \in Y$, amelyre $\pi(U, t) \cap V \neq \emptyset$ teljesül.

2.8. Definíció. Azt mondjuk, hogy a $\Lambda$ invariáns halmaz kaotikus, ha a következố három tulajdonság teljesül:

- $\pi(x, t)$ érzékenyen függ a kezdeti adatoktól $\Lambda$-n,

- $\pi(x, t)$ topologikusan tranzitív $\Lambda-n$,

- $\pi(x, t)$ periodikus pályái sürüek $\Lambda$-ban. 
2.9. Definíció. Legyen $F: \mathbb{R}^{m} \rightarrow \mathbb{R}^{m}$. Azt mondjuk, hogy az $A \subset \mathbb{R}^{m}$ halmaz attraktor, ha rendelkezik a következố tulajdonságokkal:

- invariáns, azaz $F(A)=A$,

- sürú, azaz létezik A-ban olyan kezdeti pont, amelynek a pályája súrú A-ban,

- A-hoz közelrôl induló trajektóriák közel maradnak és aszimptotikusan tartanak A-hoz.

2.10. Definíció. $A z A \subset X$ attraktort különös attraktornak nevezzük, $h a$ kaotikus.

2.11. Definíció. Egy attraktor medencéje azon pontok halmaza, amelyekból induló trajektóriák az attraktorhoz tartanak. 


\section{3. fejezet}

\section{A Tusnády-modell}

\subsection{A Tusnády-modell}

Az élőlények sejtjei - kevés kivételtól eltekintve - sejtmagot tartalmaznak, amelyben a genetikai program kromoszómák formájában tárolódik. A kromoszómák száma fajonként különböző (az embernél ez a szám 46). A kromoszómák egyik fele anyai, a másik apai eredetú, tehát a kromoszómák párokban jelennek meg, és egy-egy pár két tagját nevezzük homológ kromoszómáknak. Amikor egy ilyen diploid sejt osztódik, minden kromoszóma megkettôzôdik, és a két származéksejt mindegyike megkapja a teljes kromoszómakészletet. A szervezet tartalmaz haploid sejteket is, amelyekben csak feleannyi kromoszóma található, minden párból az egyik: ezek a sejtek a csírasejtek vagy gaméták. E sejtek a diploid sejtekből jönnek létre a meiózis folyamata során, amely kettéhasítja a kromoszómapárokat. A különbözô kromoszómapárok egymástól függetlenül bomlanak fel. Megtermékenyítéskor a gamétapárok egyesülnek, így helyreáll az eredeti kromoszómaszám.

A kromoszóma azon szakaszait, amelyek a különböző tulajdonságokat meghatározzák, génnek nevezzük. A géneknek különbözô változatai lehetnek, ezeket a változatokat alléloknak, a kromoszómán belül elfoglalt helyüket pedig lókusznak nevezzük. Haploid sejtekben minden génnek egy, diploid sejtekben két allélja lehet jelen. A genotipust a valóban jelen lévô allélpár ha- 

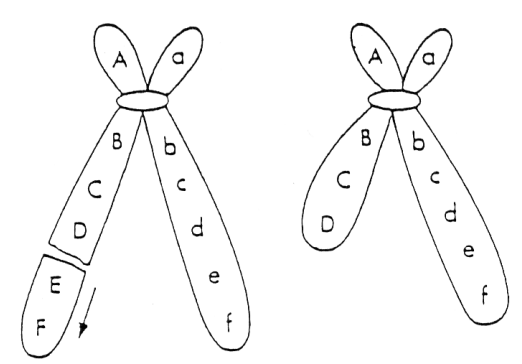

a) kiesés

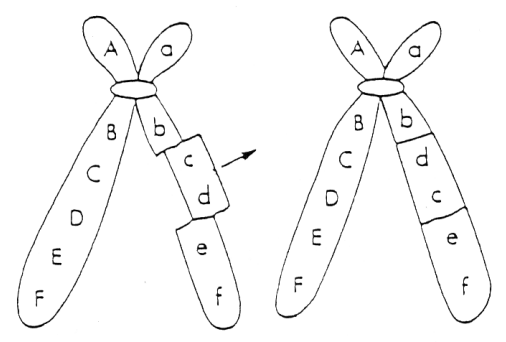

c) megiordulás

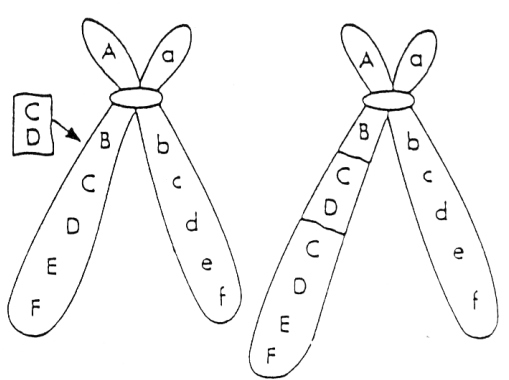

b.) kerrözödés

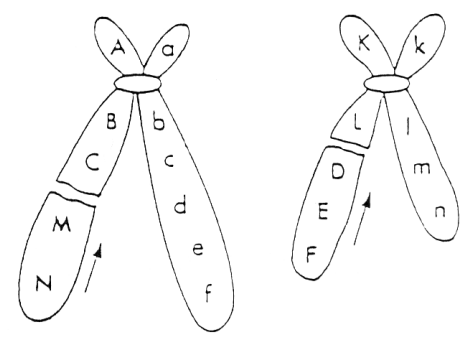

d) áthelyezödés

3.1. ábra. A mutáció típusai

tározza meg. Ha a két allél megegyezik, akkor az adott génre nézve az egyed homozigóta, ha a két allél eltérô, akkor heterozigóta. A genotípusok eloszlásának változását több tényezô is befolyásolja, amelyek közül a legfontosabbak a mutáció és a szelekció.

A szelekció azt jelenti, hogy a különbözô genotípusoknak különbözô az esélye a felnôttkor megérésére és utódok létrehozására. Valamely genotípus sikerességét a fitness, vagyis a genetikai rátermettség mutatja meg, amit többféleképpen is mérhetünk. A legegyszerúbb a Wright-féle fitness, amely az utódok várható számát jelenti.

A mutáció az örökítôanyag, a DNS rendellenes megváltozása. Ez azt jelenti, hogy a gének nem pontosan másolódnak. A mutáció leggyakrabban a meiózis alatt fordul elő; valamely allél egy másik alléllá alakul át. Valahányszor a sejtmag lemásolódik, hiba keletkezhet. Ezt többek között valamilyen 


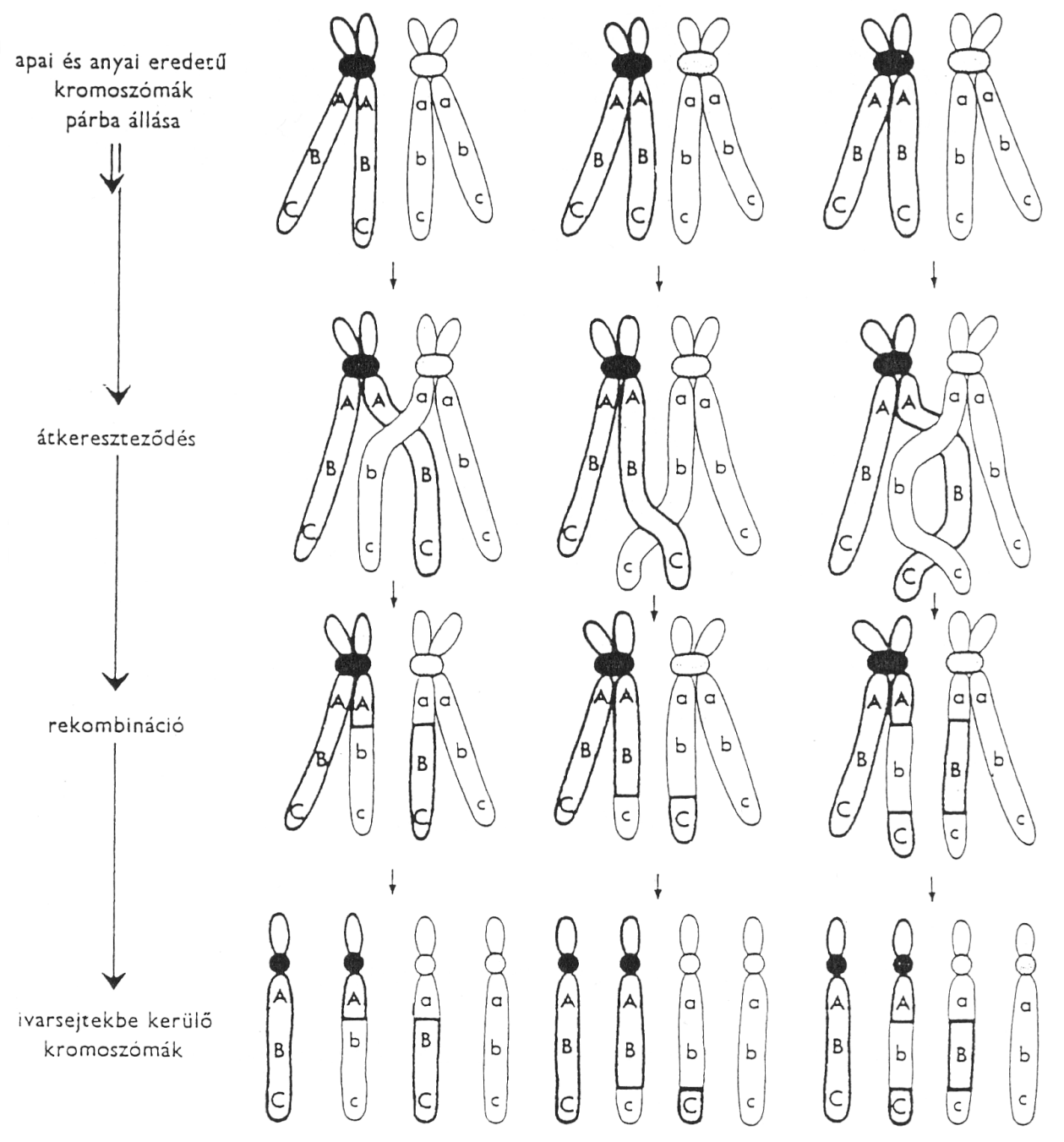

3.2. ábra. A rekombináció típusai

sugárzás okozhatja. Az eredmény néha hasznos, néha káros, de a legtöbb esetben közömbös. Másolási hibák okozzák a rákot, de a fajok kialakulását is a mutációk eredményezik, és mutációk tartják fenn azokat a velünk született rendellenességeket, amelyek gyakorisága a szelekció hatására néhány generáció során elhanyagolhatóra csökkenne.

A rekombináció vagy átkeresztezôdés a homológ kromoszómák között történhet. A rekombináció - a mutációhoz hasonlóan - a genetikai változatosság 
forrása, de itt nem új gének születnek, hanem új génkombinációk: a homológ kromoszómapárok egyes génjei kicserélődnek. Így a keletkezô ivarsejt kromoszómái nem pontos másai sem az apai, sem az anyai kromoszómáknak. Persze nem cserélődhet ki bármely két gén; minél közelebb van két lókusz egymáshoz, annál valószínúbb, hogy alléljaik a meiózis során ugyanazon a kromoszómán maradnak. Ezt a valószínúséget a kapcsoltság mértéke fejezi ki.

Modellezzük matematikilag az elóbbi fogalmakat:

Jelölje $m$ a lókuszok számát, az allélok számát pedig jelöljük $d$-vel. Ekkor az ivarsejtek $d$ dimenziós vektorokként foghatók fel, amelyek elemei az allélok:

$$
V=\left(v_{1}, \ldots, v_{m}\right)
$$

Így az ivarsejtek lehetséges száma $n=d^{m}$, jelölje óket $1, \ldots, n$.

Legyen $x_{i}(r)$ az $i$-edik ivarsejt aránya az $r$-edik generációban, ekkor nyilván teljesül, hogy $x_{1}+\cdots+x_{n}=1$.

Jelölje $\Gamma$ a genotípusok halmazát. Ekkor a $\gamma \in \Gamma$ genotípus egy véges véletlen $m \times 2$-es mátrix, ahol $m$ a lókuszok száma, a 2 pedig a nemek számát jelenti. A két oszlop független, a sorok nem feltétlenül.

A fitnessfüggvény egy leképezés $\Gamma$-ról a [0,1] zárt intervallumra.

A meiózis véletlen leképezés $\Gamma$-ról az ivarsejtek $m$ dimenziós terébe: $\Gamma \ni$ $\gamma \mapsto V, V(p)=\gamma\left(p, \varepsilon_{p}\right)$, ahol $1 \leq p \leq m, V(p)$ a $V p$-edik koordinátája, $\gamma(p, q)$ a $\gamma p$-edik sorának $q$-adik eleme és $\varepsilon_{p}(p=1, \ldots, m)$ független, azonos eloszlású véletlen változók, melyekre $P\left(\varepsilon_{p}=1\right)=P\left(\varepsilon_{p}=2\right)=\frac{1}{2}$.

A mutáció eredménye Tusnády Gábor szerint mindkét szülői géntől függ a következố módon [21].

Jelölje $w(i, j)$ az $i j$ genotípus fitnessét $(0 \leq w(i, j) \leq 1)$, és legyen $\left\{y_{i j}\right\}_{i, j=1}^{n}$ a genotípusok eloszlása egy adott generációban. Ha csak a szelekciót vesszük figyelembe (eltekintünk a mutációtól és a rekombinációtól), 
akkor a következô szelekciós modellt kapjuk:

$$
y_{i j}=\frac{w(i, j) x_{i} x_{j}}{\sum_{p, q=1}^{n} w(p, q) x_{p} x_{q}}, i, j=1, \cdots, n \text {. }
$$

Vegyük ezután figyelembe a rekombinációt és a mutációt is. Jelölje $M_{i j}(k)$ annak a valószínúségét, hogy az $i j$ genotípusú sejtból $k$ típusú ivarsejt jön létre. $M_{i j}(k)$ magában foglalja a rekombinációt és a mutációt is. Ekkor a meiózis után az ivarsejtek új eloszlását a következőképpen kapjuk meg:

$$
x_{k}(r+1)=\sum_{i, j=1}^{n} y_{i j}(r) M_{i j}(k) .
$$

Ha behelyettesítjük $y_{i j}$ helyére a szelekciós modellben kapott képletet és bevezetjük az $a(i, j, k)=w(i, j) M_{i j}(k)$ jelölést, akkor a következô modellt kapjuk:

$$
x_{k}(r+1)=\frac{\sum_{i, j=1}^{n} a(i, j, k) x_{i}(r) x_{j}(r)}{\sum_{i, j, k=1}^{n} a(i, j, k) x_{i}(r) x_{j}(r)} .
$$

Tusnády Gábor azt vizsgálta, hogy mit lehet mondani a leképezés iterációjával kapott sorozatok torlódási pontjairól, illetve hogy egyáltalán van-e olyan rendszer, amelyben több torlódási pont van. Numerikus kísérleteket végzett, és azt tapasztalta, hogy az is ritka, amikor valamilyen görbe a torlódási halmaz. Ezekben az esetekben mindig ugyanaz volt a torlódási halmaz, akármelyik pontból indult ki. Talált olyan esetet is, amikor a görbe két összefüggố komponensre esett szét, és az is előfordult, hogy a torlódási halmaz véges sok pontból állt. Néha olyan fixpontokhoz jutott, amelyekhez más pontból indulva nem volt konvergencia. A legtöbb esetben azonban ezek a véletlen keresések egyetlen fixpontú leképezésre vezettek. Sokáig azt hitte, hogy egy bizonyos monotonitás biztosítja, hogy egyetlen fixpont legyen, mégpedig az, hogy minden egyes gén ad egy virtuális skálán valamilyen értéket, ezeket az értékeket összeadjuk, és a szelekciós valószínúség az így kapott összeg monoton függvénye.

Egy ellenpélda azonban meggyőzte arról, hogy ez nincs így: a monotonitás mellett is lehet a rendszernek több fixpontja, saját vonzási tartománnyal. 
Végül hosszas keresés után a következô négydimenziós rendszert találta:

$$
\begin{array}{ll}
a(2,4,1)=1042 & \\
a(2,4,2)=8 & a(3,4,2)=113 \\
a(1,2,3)=19 & a(2,3,3)=9 \\
a(1,3,4)=1078 & a(2,2,4)=414
\end{array}
$$

Ez úgy olvasandó, hogy minden $i, j, k$ mellett $a(i, j, k)=a(j, i, k)$ és a nem említett együtthatók értéke nulla. Vagyis a rendszerünk a következô:

$$
x(r+1)=\left(\begin{array}{c}
\frac{2084 x_{2} x_{4}}{38 x_{1} x_{2}+414 x_{2}^{2}+2156 x_{1} x_{3}+18 x_{2} x_{3}+2100 x_{2} x_{4}+226 x_{3} x_{4}} \\
\frac{16 x_{2} x_{4}+226 x_{3} x_{4}}{38 x_{1} x_{2}+414 x_{2}^{2}+2156 x_{1} x_{3}+18 x_{2} x_{3}+2100 x_{2} x_{4}+226 x_{3} x_{4}} \\
\frac{38 x_{1} x_{2}+18 x_{2} x_{3}}{38 x_{1} x_{2}+414 x_{2}^{2}+2156 x_{1} x_{3}+18 x_{2} x_{3}+2100 x_{2} x_{4}+226 x_{3} x_{4}} \\
\frac{414 x_{2}^{2}+2156 x_{1} x_{3}}{38 x_{1} x_{2}+414 x_{2}^{2}+2156 x_{1} x_{3}+18 x_{2} x_{3}+2100 x_{2} x_{4}+226 x_{3} x_{4}}
\end{array}\right)
$$

E rendszer torlódási halmaza nem egydimenziós. Valószínúleg kettô a torlódási pontok halmazának a dimenziója, és ezen a rendszer viselkedése már a közönséges szemlélő előtt is kaotikusnak tûnik.

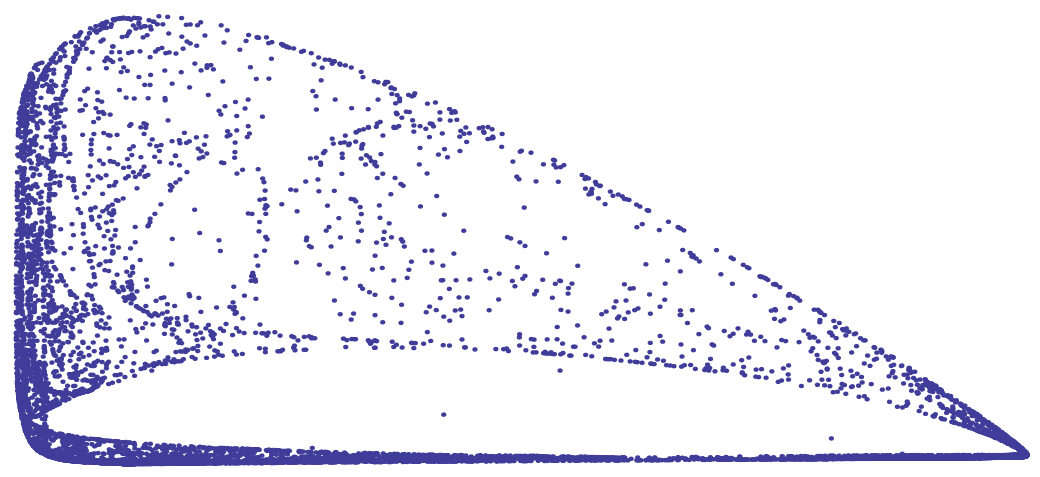

3.3. ábra. A Tusnády-rendszer torlódási pontjainak halmaza

Vizsgáljuk, hogy hogyan változik a rendszer viselkedése, ha változtatjuk valamelyik együtthatót.

A legtöbb esetben ha egy paraméter értékét csak egy kicsit változtatjuk meg, akkor a rendszer dinamikája, a megoldások szerkezete nem változik, 
ezt nevezzük strukturális stabilitásnak. Vannak viszont olyan esetek, a paraméternek olyan kritikus értékei, amikor a paraméter kis változtatására is lényegesen megváltozik a dinamika, a trajektóriák lényegesen eltérnek a kritikus érték alatti és fölötti paraméterekre. Ezt a jelenséget nevezzük bifurkációnak. Ez jelentheti például egyensúlyi helyzetek vagy periodikus megoldás megjelenését, illetve eltûnését vagy stabilitásuk változását.

3.1. Definíció. $A z\left(X_{1}, \pi_{1}\right)$ és az $\left(X_{2}, \pi_{2}\right)$ dinamikus rendszerek topologikusan ekvivalensek, ha létezik $h: X_{1} \rightarrow X_{2}$ homeomorfizmus (azaz h invertálható leképezés úgy, hogy $h$ és az inverze is folytonos), amely az elsố rendszer pályáit a második rendszer pályáira képezi, megốrizve az idő irányítását.

3.2. Definíció. Tekintsünk egy paramétertól függő dinamikus rendszert. Azt a jelenséget, amikor egy paraméter változtatása során topologikusan nem ekvivalens fáziskép jelenik meg, bifurkációnak nevezzük.

A paraméternek azt az értékét, ahol a bifurkáció bekövetkezik, bifurkációs vagy kritikus értéknek nevezzük.

3.3. Definíció. Tekintsük a következô diszkrét dinamikus rendszert:

$$
x \mapsto f(x),
$$

ahol $f$ diffeomorfizmus, azaz $f$ inverzével együtt differenciálható. Legyen $x_{0}$ e rendszer fixpontja (azaz $x_{0}=f\left(x_{0}\right)$ ), és jelölje $A$ a az $f(x)$ Jacobi-mátrixát $x_{0}$-ban. Jelölje az $A$ mátrix sajátértékeit $\mu_{1}, \mu_{2}, \ldots, \mu_{n}$.

Azt mondjuk, hogy az $x_{0}$ egyensúlyi helyzet hiperbolikus, ha A-nak nincs sajátértéke a komplex sík origó körüli egységkörén.

3.4. Definíció. Tekintsünk egy paramétertól függô diszkrét dinamikus rendszert:

$$
x_{r+1}=F\left(x_{r}, \alpha\right), \quad F: \mathbb{R}^{n} \times \mathbb{R} \rightarrow \mathbb{R}^{n},
$$

ahol $F$ sima $x$-ben és $\alpha$-ban is. Legyen $x=x_{0}$ a rendszer nemhiperbolikus fixpontja $\alpha=\alpha_{0}$-ra. Azt a jelenséget, amikor $\alpha$ változtatásakor a $\frac{\partial F}{\partial x}\left(x_{0}, \alpha\right)$ Jacobi-mátrix sajátértékei áthaladnak az origó körüli egységkörön, NeimarkSacker-bifurkációnak nevezzük. 
Amennyiben egy stabil fixpontból egy stabil zárt invariáns görbe bifurkálódik, míg a fixpont instabillá válik, szuperkritikus Neimark-Sacker-bifurkációról beszélünk, azt az esetet pedig, amikor egy instabil fixpontból egy instabil zárt invariáns görbe bifurkálódik, miközben a fixpont stabillá válik, szubkritikus Neimark-Sacker-bifurkációnak nevezzük.
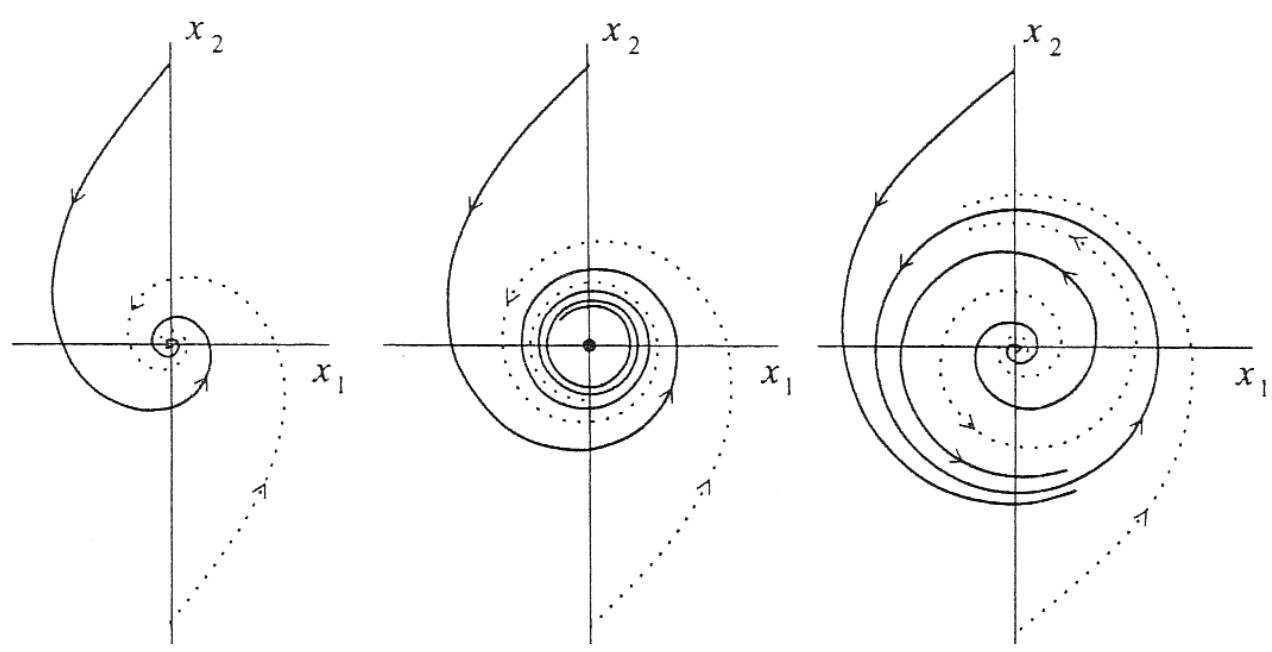

3.4. ábra. Szuperkritikus Neimark-Sacker-bifurkáció

Vizsgáljuk elôször a rendszert különbözô paraméterértékeknél a 4. fejezetben ismertetett attraktorszámító program segítségével. Válasszuk paraméternek a $p=a(2,4,2)=a(4,2,2)=8$ együtthatót.

A 3.6. ábrán, amely a rendszert az eredeti, Tusnády Gábor által meghatározott együtthatókkal ábrázolja, jól látszik a kaotikus viselkedés.

A 3.7. ábra a rendszer globális attraktorát mutatja, $p=135$ paraméterértéknél készültt és látszik, hogy itt az attraktor egy stabil zárt görbe.

A $p=145$ paraméterértéknél a program által készített ábra azt mutatja, hogy az attraktor egy stabil fixpont.

A kaotikus viselkedés matematikai bizonyítása még várat magára, de a paraméter értékének növelésével bekövetkező jelenséget tisztázzuk a következókben. 

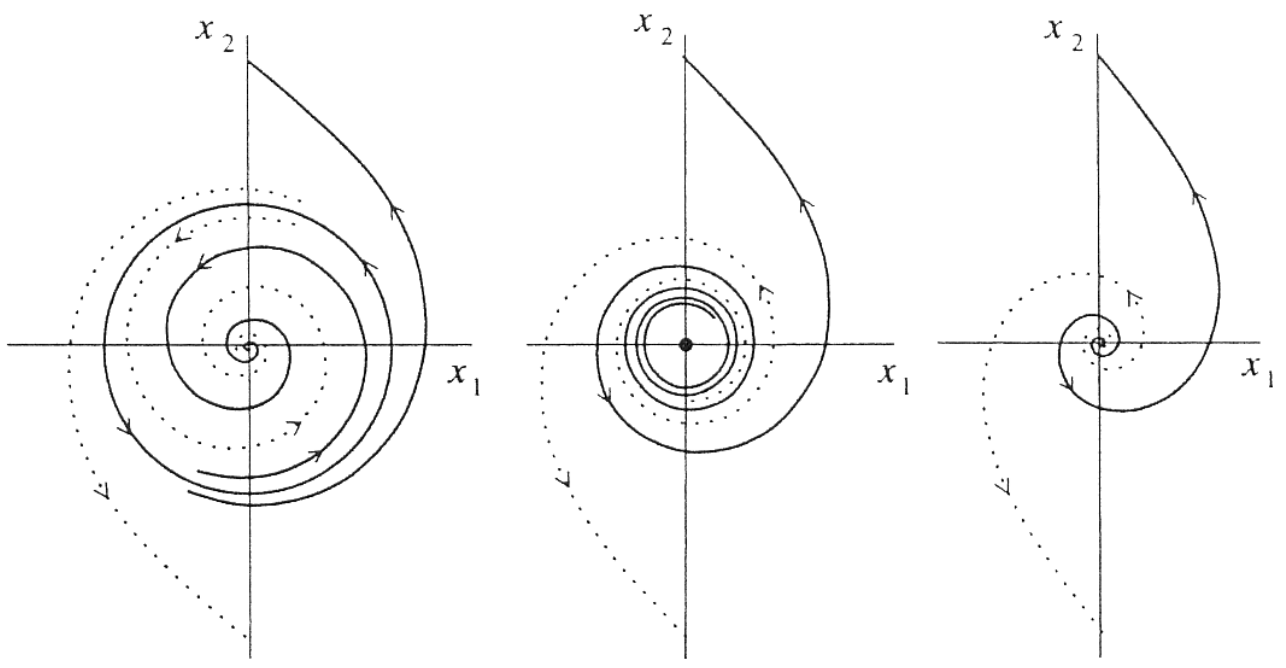

3.5. ábra. Szubkritikus Neimar-Sacker-bifurkáció

A program által készített ábrák Neimark-Sacker-bifurkációra utalnak, hiszen a paraméter változtatásával egy stabil fixpontból egy zárt görbe keletkezett.

A 3.8. ábra a rendszer teljes dinamikáját mutatja a fázistérben. Mivel az allélok eloszlásainak összege 1 , a rendszert három dimenzióra redukálhatjuk. A fázistér a négydimenziós szimplex, vagyis egy tetraéder. A $p$ paraméter értékének változtatásával a Jacobi-mátrix komplex sajátértékpárja áthalad az egységkörön. Ennek a komplex sajátértékpárnak megfelel a fixpont kétdimenziós instabil sokasága. Az invariáns zárt görbe ezen az instabil sokaságon jelenik meg. A fixpontnak van egy stabil sokasága is; az instabil sokaság vonzza a megoldásokat. A $p=139,455$ paraméterértéknél a két sajátérték abszolút értéke 1. Annak igazolásához, hogy e paraméterértéknél bifurkáció történik, be kell látnunk, hogy a rendszer teljesít bizonyos nemelfajulási feltételeket.

3.5. Tétel. A (3.1) Tusnády-rendszer a $p=139,455$ paraméterértéknél szuperkritikus Neimark-Sacker-bifurkáción megy keresztül, azaz egy stabil fixpontból egy stabil invariáns zárt görbe bifurkálódik, miközben a fixpont instabillá válik. 


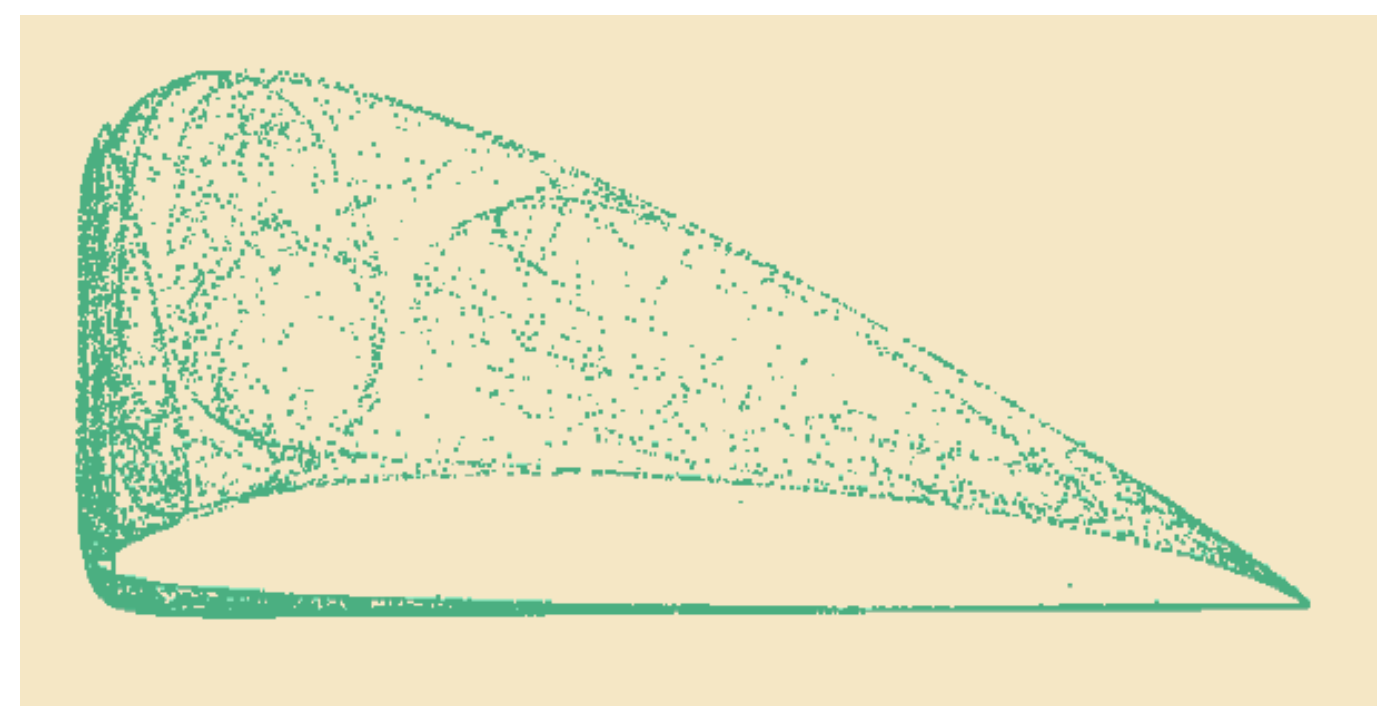

3.6. ábra. A Tusnády-rendszer attraktora $p=8$ paraméterértéknél

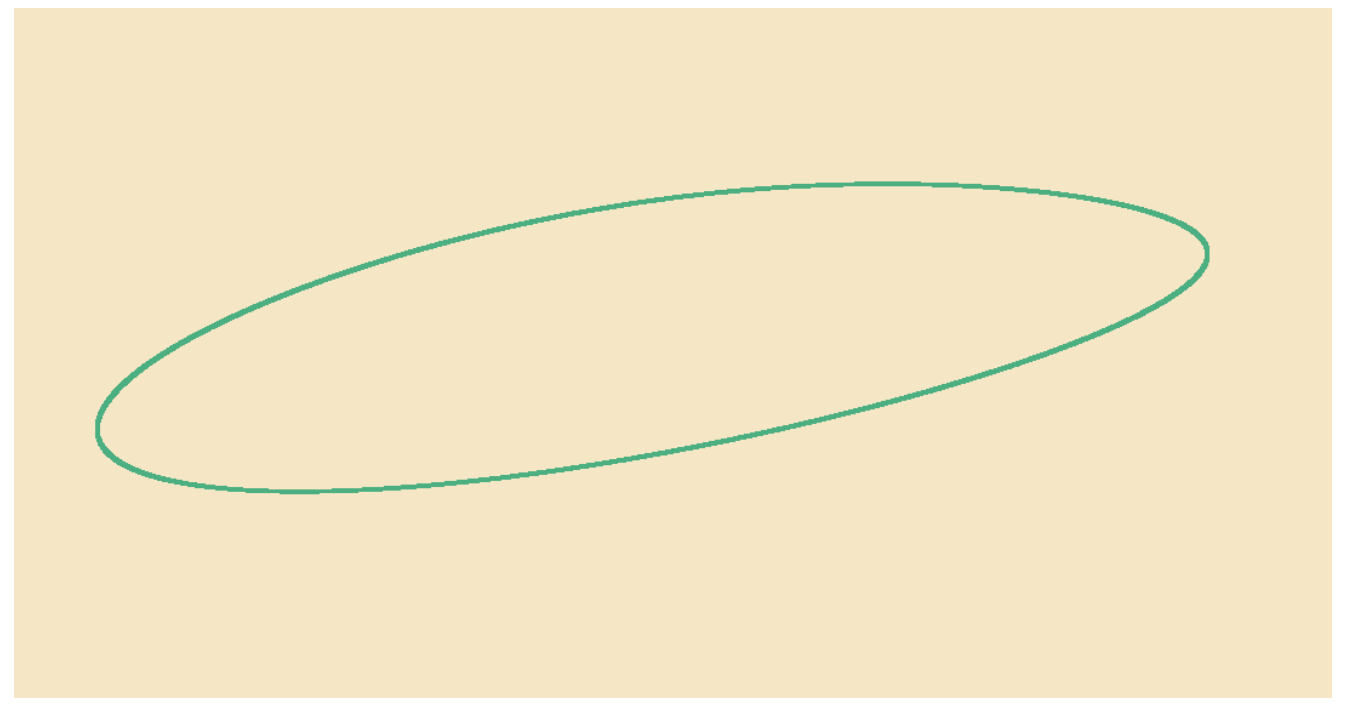

3.7. ábra. A Tusnády-rendszer attraktora $p=135$ paraméterértéknél 


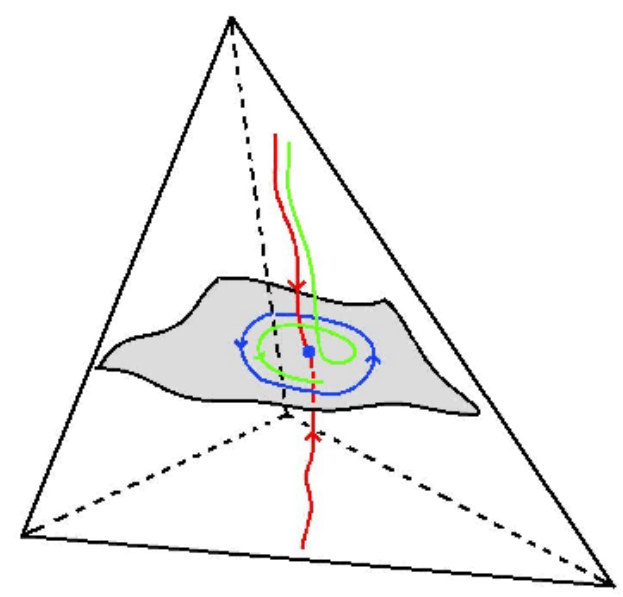

3.8. ábra. A Tusnády-rendszer dinamikája

\subsection{A 3.5. tétel bizonyítása}

A 3.5. tételben a $p=a(2,4,2)=a(4,2,2)$ paramétert változtatjuk. A paraméter változásával a Jacobi-mátrix komplex sajátértékpárja áthalad a komplex sík origó körüli egységkörén. A paraméter $p=139,455$ értékénél a sajátértékpár abszolút értéke 1. A rendszernek azonban bizonyos nemelfajulási feltételeket is teljesítenie kell ahhoz, hogy valóban a szuperkritikus NeimarkSacker-bifurkáció definíciójában leírt jelenség játszódjon le. E nemelfajulási feltételek ellenôrzése meglehetôsen hosszadalmas számítást igényel.

Először [14] alapján ismertetjük az eljárást, amely alapján végül igazolhatjuk a rendszer nemelfajulását. Az egyszerúbb jelölés kedvéért a (3.1) rendszer helyett általánosan írjuk le az eljárást.

\section{A. Kétdimenziós rendszerek}

Mivel az általános, $n$ dimenziós esetet a kétdimenziós esetre vezetjük vissza, először kimondjuk a két dimenzióra vonatkozó, általános Neimark-Sackerbifurkációs tételt. 
Tekintsük a következô kétdimenziós rendszert:

$$
x \mapsto f(x, \alpha), \quad x \in \mathbb{R}^{2}, \quad \alpha \in \mathbb{R},
$$

ahol az $f$ sima függvénynek $\alpha=0$-ban $x=0$ fixpontja a $\mu_{1,2}=e^{ \pm i \theta_{0}}, 0<\theta_{0}<$ $\pi$ egyszeres sajátértékekkel. Az implicitfüggvény-tétel szerint e rendszernek minden elegendôen kicsi $|\alpha|$ esetén egyetlen $x_{0}(\alpha)$ egyensúlyi helyzete van az origó egy környezetében. Egy paraméterfüggő koordinátatranszformációval elérhetô, hogy ez a fixpont az origóban legyen. Így feltehetjük, hogy minden elegendôen kicsi $|\alpha|$ esetén $x=0$ fixpont. Így a rendszert az

$$
x \mapsto A(\alpha) x+F(x, \alpha)
$$

alakra írhatjuk át, ahol $F$ sima vektorfüggvény, $F$ mindkét komponensének $x$ szerinti Taylor-sora legalább másodfokú taggal kezdődik, és $F(0, \alpha)=0$ minden elegendően kicsi $|\alpha|$-ra. Az $A(\alpha)$ Jacobi-mátrix két sajátértéke

$$
\mu_{1,2}=r(\alpha) e^{ \pm i \varphi(\alpha)}
$$

ahol $r(0)=1, \varphi(0)=\theta_{0}$. Így $r(\alpha)=1+\beta(\alpha)$ valamilyen sima $\beta(\alpha)$ függvényre, ahol $\beta(0)=0$. Tegyük fel, hogy $\beta^{\prime}(0) \neq 0$. Ekkor a $\beta$-t használhatjuk új paraméterként és a sajátértékeket megadhatjuk $\beta$ kifejezéseiként: $\mu_{1}(\beta)=\mu(\beta), \mu_{2}(\beta)=\bar{\mu}(\beta)$, ahol $\mu(\beta)=(1+\beta) e^{\theta(\beta)}$ és $\theta(\beta)$ sima függvény úgy, hogy $\theta(0)=\theta_{0}$.

Ahhoz, hogy a tételt kimondhassuk, egy újabb átalakításra van szükség. Errôl a technikai részletek mellőzésével itt elegendô annyit mondani, hogy egy komplex változó és egy új paraméter bevezetésével a (3.2) rendszert a következő alakra írhatjuk át minden elegendően kicsi $|\alpha|$-ra:

$$
z \mapsto \mu(\beta) z+g(z, \bar{z}, \beta)
$$

ahol $\beta \in \mathbb{R}^{1}, z \in \mathbb{C}^{1}, \mu(\beta)=(1+\beta) e^{i \theta(\beta)}$ és $g$ sima komplex értékú függvénye $z$-nek, $\bar{z}$-nek és $\beta$-nak, amelynek Taylor-sora csak másod- és annál magasabb 
fokú tagokat tartalmaz:

$$
g(z, \bar{z}, \beta)=\sum_{k+l \geq 2} \frac{1}{k ! l !} g_{k l}(\beta) z^{k} \bar{z}^{l}, \quad k, l=0,1, \ldots
$$

Az eddigiek felhasználásával a következô tételt mondhatjuk ki a NeimarkSacker-bifurkációról két dimenzióban:

3.6. Tétel (általános Neimark-Sacker-bifurkáció [14]). Tetszóleges általános kétdimenziós, egyparaméteres

$$
x \mapsto f(x, \alpha)
$$

rendszerre, amelynek $\alpha=0$-ban $x_{0}=0$ fixpontja a $\mu_{1,2}=e^{ \pm i \theta_{0}}$ sajátértékekkel, az $x_{0}$ pontnak létezik olyan környezete, amelyben egy zárt invariáns görbe bifurkálódik $x_{0}$-ból, miközben $\alpha$ áthalad a 0-n. Az általánossághoz a rendszernek a következö feltételeket kell teljesitenie:

(1) $r^{\prime}(0) \neq 0$, ahol $\mu_{1,2}(\alpha)=r(\alpha) e^{ \pm i \varphi(\alpha)}, r(0)=1, \varphi(0)=\theta_{0}$,

(2) $e^{ \pm i k \theta_{0}} \neq 1, k=1,2,3,4$,

(3) $a(0) \neq 0$, ahol $a(0)=\operatorname{Re}\left(\frac{e^{-i \theta_{0}} g_{21}}{2}\right)-\operatorname{Re}\left(\frac{\left(1-2 e^{i \theta_{0}}\right) e^{-2 i \theta_{0}}}{2\left(1-e^{i \theta_{0}}\right)} g_{20} g_{11}\right)-\frac{1}{2}\left|g_{11}\right|^{2}-$ $\frac{1}{4}\left|g_{02}\right|^{2}$, ahol $g_{i j}=g_{i j}(0)$

A (3) feltételben szereplő a(0) érték elójele határozza meg a NeimarkSacker-bifurkáció típusát: ha a(0) negativ, akkor szuperkritikus, ha a(0) pozitiv, akkor szubkritikus Neimark-Sacker-bifurkáció megy végbe.

\section{B. Magasabb dimenziós rendszerek}

Magasabb dimenziós rendszereknél lényegében ugyanaz történik, mint két dimenzióban: létezik egy kétdimenziós invariáns sokaság, amelyen a rendszer bifurkáción megy át, a sokaságon kívül pedig a rendszer viselkedése „triviális”, mert ott nincs bifurkáció.

Tekintsük az

$$
x \mapsto f(x), \quad x \in \mathbb{R}^{n}
$$


leképezés által meghatározott diszkrét dinamikus rendszert, ahol $f$ elegendôen sima és $f(0)=0$. Legyenek az $A$ Jacobi-mátrix sajátértékei az $x_{0}=0$ pontban $\mu_{1}, \mu_{2}, \ldots, \mu_{n}$. Tegyük fel, hogy az egyensúlyi helyzet nem hiperbolikus, vagyis hogy vannak egységnyi abszolút értékú sajátértékek, jelöljük ezek számát $n_{0}$-lal. Jelölje az $A$-nak az egységkörön elhelyezkedő sajátértékekhez tartozó lineáris invariáns (általánosított) sajátalterét $T^{c}$. Ekkor létezik egy lokálisan definiált, $n_{0}$ dimenziós $W_{l o c}^{c}(0)$ invariáns sokaság, amelyet $T^{c}$ érint az $x=0$ pontban. Ezenkívül létezik $x_{0}$-nak egy $U$ környezete úgy, hogy ha $f^{k}(x) \in U$ minden $k \in \mathbb{N}$, akkor $f^{k}(x) \rightarrow W_{l o c}^{c}(0)$

A $W_{l o c}^{c}(0)$ sokaságot centrális sokaságnak nevezzük. A rendszerünket a következő alakba írhatjuk át:

$$
\left(\begin{array}{l}
u \\
v
\end{array}\right) \mapsto\left(\begin{array}{c}
B u+g(u, v) \\
C v+h(u, v)
\end{array}\right)
$$

ahol a $B$ mátrix sajátértékei az egységkörön helyezkednek el, a $C$ mátrix sajátértékei pedig azon kívül vagy belül, és a következô redukciós elvet alkalmazhatjuk:

A (3.3) rendszer lokálisan topologikusan ekvivalens az origó közelében a következô rendszerrel:

$$
\left(\begin{array}{l}
u \\
v
\end{array}\right) \mapsto\left(\begin{array}{c}
B u+g(u, V(u)) \\
C v
\end{array}\right)
$$

\section{Eljárás a nemelfajulás bizonyítására}

A (3.3) alakot azonban ritkán használjuk, egy hasznos módszer segítségével elkerülhetjük az elôbbi transzformációt. A gyakorlatban általában ezt a módszert használjuk a különbözô rendszerek vizsgálatánál. Ennél a módszernél csak az $A$ mátrix és transzponáltja, $A^{T}$ kritikus sajátértékeihez tartozó sajátvektorokat használjuk, hogy „levetítsük” a rendszert a kritikus sajátaltérbe.

Írjuk fel a rendszert

$$
\tilde{x}=A x+F(x), \quad x \in \mathbb{R}^{n}
$$


alakban, ahol $F(x)=O\left(\|x\|^{2}\right)$ sima függvény.

Tudjuk, hogy a Neimark-Sacker-bifurkáció esetében az A Jacobi-mátrixnak van egy komplex sajátértékpárja, amely az egységkörre esik: $\mu_{1,2}=e^{ \pm i \theta_{0}}, 0<$ $\theta_{0}<\pi$ és ezeken kívül nincs $A$-nak más sajátértéke, amely egységnyi abszolút értékú. Legyen $q \in \mathbb{C}^{n}$ egy $\mu_{1}$-hez tartozó komplex sajátvektor:

$$
A q=e^{i \theta_{0}} q, \quad A \bar{q}=e^{-i \theta_{0}} \bar{q}
$$

Vezessük be a $p \in \mathbb{C}^{n}$ sajátvektort, amely a következô tulajdonságokkal rendelkezik:

$$
A^{T} p=e^{-i \theta_{0}} p, \quad A^{T} \bar{p}=e^{i \theta_{0}} \bar{p}
$$

és

$$
\langle p, q\rangle=1
$$

ahol $\langle p, q\rangle=\sum_{i=1}^{n} \bar{p}_{i} q_{i}$ a szokásos $\mathbb{C}^{n}$-beli skalárszorzás. A $\mu_{1,2}$-höz tartozó $T^{c}$ kritikus sajátaltér kétdimenziós, és $\operatorname{Re} q, \operatorname{Im} q$ kifeszíti. A $T^{s u}$ valós sajátaltér, amely az $A$ többi sajátértékéhez tartozik, $(n-2)$ dimenziós.

Igaz a következô: $y \in T^{s u}$ akkor és csak akkor teljesül, ha $\langle p, y\rangle=0$.

Jegyezzük meg, hogy $y \in \mathbb{R}^{n}$ valós, míg $p \in \mathbb{C}^{n}$ komplex. Így az elóbbi feltétel két megszorítást jelent $y$-ra: $\langle p, y\rangle$ valós és képzetes része egyaránt eltünik.

Ez alapján felbonthatjuk $x \in \mathbb{R}^{n}$-t

$$
x=z q+\overline{z q}+y
$$

alakban, ahol $z \in \mathbb{C}^{1}, z q+\overline{z q} \in T^{c}$ és $y \in T^{s u}$. Így a következőt kapjuk:

$$
\left\{\begin{array}{l}
z=\langle p, x\rangle \\
y=x-\langle p, x\rangle q-\langle\bar{p}, x\rangle \bar{q}
\end{array}\right.
$$

Ezekkel a koordinátákkal a (3.4) leképezést a következő alakra hozhatjuk: 


$$
\left\{\begin{aligned}
\tilde{z}= & e^{i \theta_{0}} z+\langle p, F(z q+\overline{z q}+y)\rangle \\
\tilde{y}= & A y+F(z q+\overline{z q}+y) \\
& -\langle p, F(z q+\overline{z q}+y)\rangle q \\
& -\langle\bar{p}, F(z q+\overline{z q}+y)\rangle \bar{q}
\end{aligned}\right.
$$

Ez a rendszer $(n+2)$ dimenziós, azonban $y$-ra van két megszorítás.

Írjuk fel $F(x)$-et a következő alakban:

$$
F(x)=\frac{1}{2} B(x, x)+\frac{1}{6} C(x, x, x)+O\left(\|x\|^{4}\right),
$$

ahol $B(x, y)$ és $C(x, y, z)$ multilineáris függvények. Koordinátákkal:

$$
B_{i}(x, y)=\left.\sum_{j, k=1}^{n} \frac{\partial^{2} F_{i}(\xi)}{\partial \xi_{j} \partial \xi_{k}}\right|_{\xi=0} x_{j} y_{k}
$$

és

$$
C_{i}(x, y, z)=\left.\sum_{j, k, l=1}^{n} \frac{\partial^{3} F_{i}(\xi)}{\partial \xi_{j} \partial \xi_{k} \partial \xi_{l}}\right|_{\xi=0} x_{j} y_{k} z_{l}
$$

és $i=1,2, \ldots, n$. Ezek a függvények megkönnyítik a Taylor-együtthatók kiszámítását.

A (3.7) rendszert a következő alakra írhatjuk át Taylor-sorba fejtve:

$$
\left\{\begin{aligned}
\tilde{z}= & e^{i \theta_{0}} z+\frac{1}{2} G_{20} z^{2}+G_{11} z \bar{z}+\frac{1}{2} G_{02} \bar{z}^{2}+\frac{1}{2} G_{21} z^{2} \bar{z} \\
& +\left\langle G_{10}, y\right\rangle z+\left\langle G_{01}, y\right\rangle \bar{z}+\cdots \\
\tilde{y}= & A y+\frac{1}{2} H_{20} z^{2}+H_{11} z \bar{z}+\frac{1}{2} \bar{z}^{2}+\cdots
\end{aligned}\right.
$$

ahol $G_{20}, G_{11}, G_{02}, G_{21} \in \mathbb{C}^{1} ; G_{01}, G_{10}, H_{i j} \in \mathbb{C}^{n}$. A (3.10)-ben szereplö komplex számokat és vektorokat a következô formulák alapján kaphatjuk meg:

$$
\begin{aligned}
G_{20} & =\langle p, B(q, q)\rangle & G_{11} & =\langle p, B(q, \bar{q})\rangle \\
G_{02} & =\langle p, B(\bar{q}, \bar{q})\rangle & G_{21} & =\langle p, C(q, q, \bar{q})\rangle \\
\left\langle G_{10}, y\right\rangle & =\langle p, B(q, y)\rangle & \left\langle G_{01}, y\right\rangle & =\langle p, B(\bar{q}, y)\rangle
\end{aligned}
$$




$$
\begin{aligned}
& H_{20}=B(q, q)-\langle p, B(q, q)\rangle q-\langle\bar{p}, B(q, q)\rangle \bar{q} \\
& H_{11}=B(q, \bar{q})-\langle p, B(q, \bar{q})\rangle q-\langle\bar{p}, B(q, \bar{q})\rangle \bar{q}
\end{aligned}
$$

(3.10)-ben a centrális sokaság reprezentációja:

$$
y=V(z, \bar{z})=\frac{1}{2} w_{20} z^{2}+w_{11} z \bar{z}+\frac{1}{2} w_{02} \bar{z}^{2}+O\left(|z|^{3}\right),
$$

ahol $\left\langle p, w_{i j}\right\rangle=0$. A $w_{i j} \in \mathbb{C}^{n}$ vektorokat az

$$
\left\{\begin{aligned}
\left(e^{2 i \theta_{0}} E-A\right) w_{20} & =H_{20}, \\
(E-A) w_{11} & =H_{11}, \\
\left(e^{-2 i \theta_{0}} E-A\right) w_{02} & =H_{02}
\end{aligned}\right.
$$

lineáris egyenletekból kaphatjuk meg. Az egyenleteknek egyetlen megoldása van. $\mathrm{Az}(E-A)$ mátrix invertálható, mert az 1 nem sajátértéke $A$-nak $\left(e^{i \theta_{0}} \neq\right.$ 1). $\mathrm{Ha}$

$$
e^{3 i \theta_{0}} \neq 1
$$

az $\left(e^{ \pm 2 i \theta_{0}} E-A\right)$ mátrixok is invertálhatók $\mathbb{C}^{n}$-ben, mert $e^{ \pm 2 i \theta_{0}}$ nem sajátértéke $A$-nak. Így a megszorított leképezést a következő formában írhatjuk:

$$
\begin{aligned}
\tilde{z}= & i w_{0} z+\frac{1}{2} G_{20} z^{2}+G_{11} z \bar{z}+\frac{1}{2} G_{02} \bar{z}^{2} \\
& +\frac{1}{2}\left(G_{21}+2\left\langle p, B\left(q,(E-A)^{-1} H_{11}\right)\right\rangle\right. \\
& \left.+\left\langle p, B\left(\bar{q},\left(e^{2 i \theta_{0}} E-A\right)^{-1} H_{20}\right)\right\rangle\right) z^{2} \bar{z}+\cdots
\end{aligned}
$$

Ezt, felhasználva a $G_{i j}$-k és $H_{i j}$-k korábbi definícióit, valamint a következő 
azonosságokat:

$$
\begin{aligned}
(E-A)^{-1} q & =\frac{1}{1-e^{i \theta_{0}}} q, \\
\left(e^{2 i \theta_{0}} E-A\right)^{-1} q & =\frac{e^{-i \theta_{0}}}{e^{i \theta_{0}}-1} q, \\
(E-A)^{-1} \bar{q} & =\frac{1}{1-e^{-i \theta_{0}}} \bar{q}, \\
\left(e^{2 i \theta_{0}} E-A\right)^{-1} \bar{q} & =\frac{e^{i \theta_{0}}}{e^{3 i \theta_{0}}-1} \bar{q},
\end{aligned}
$$

a következóképpen írhatjuk fel:

$$
\tilde{z}=e^{i \theta_{0}} z+\frac{1}{2} g_{20} z^{2}+g_{11} z \bar{z}+\frac{1}{2} g_{02} \bar{z}^{2}+\frac{1}{2} g_{21} z^{2} \bar{z}+\cdots,
$$

ahol

$$
\begin{aligned}
g_{20}= & \langle p, B(q, q)\rangle, \\
g_{11}= & \langle p, B(q, \bar{q})\rangle, \\
g_{02}= & \langle p, B(\bar{q}, \bar{q})\rangle \\
g_{21}= & \left\langle p, C(q, q, \bar{q})+2\left\langle p, B\left(q,(E-A)^{-1} B(q, \bar{q})\right)\right\rangle\right. \\
& +\left\langle p, B\left(\bar{q},\left(e^{2 i \theta_{0}} E-A\right)^{-1} B(q, q)\right)\right\rangle \\
& +\frac{e^{-i \theta_{0}}\left(1-2 e^{i \theta_{0}}\right)}{1-e^{i \theta_{0}}}\langle p, B(q, q)\rangle\langle p, B(q, \bar{q})\rangle \\
& -\frac{2}{1-e^{-i \theta_{0}}}|\langle p, B(q, \bar{q})\rangle|^{2}-\frac{e^{i \theta_{0}}}{e^{3 i \theta_{0}}-1}|\langle p, B(\bar{q}, \bar{q})\rangle|^{2} .
\end{aligned}
$$

A kétdimenziós esethez hasonlóan, ha

$$
e^{i k \theta_{0}} \neq 1, k=1,2,3,4
$$

akkor a megszorított leképezést a következő alakra hozhatjuk:

$$
\tilde{z}=e^{i \theta_{0} z}\left(1+d(0)|z|^{2}\right)+O\left(|z|^{4}\right),
$$

ahol az $a(0)=\operatorname{Re} d(0)$ valós szám határozza meg a zárt invariáns görbe 


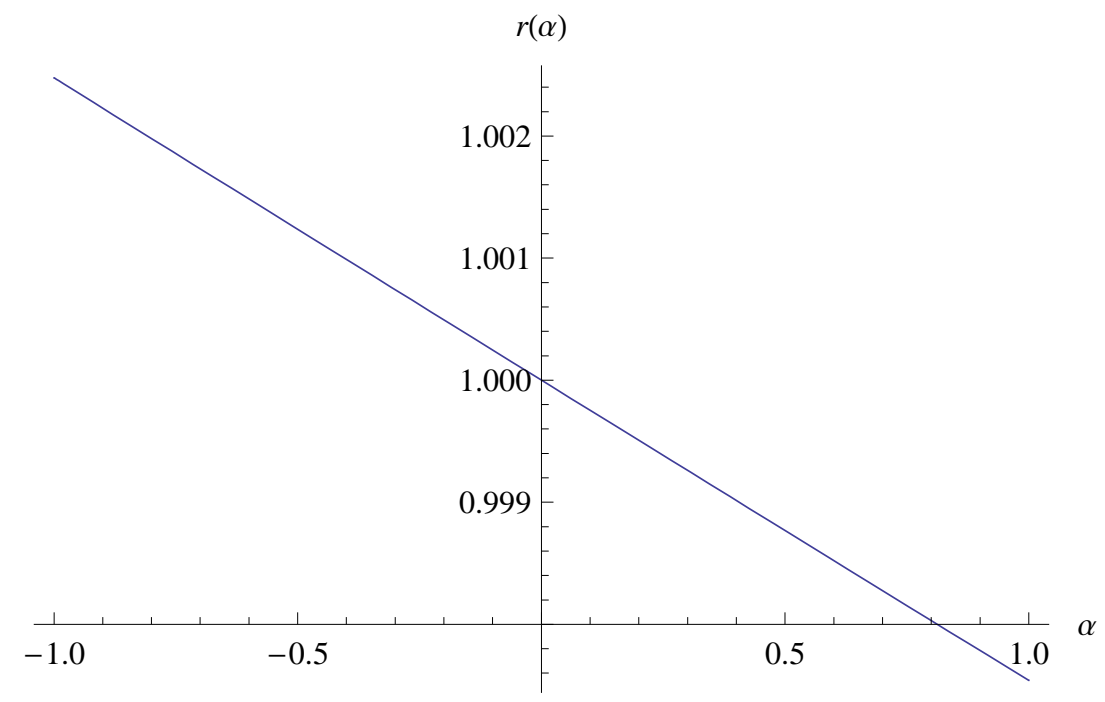

3.9. ábra. $r$ interpolációs függvénye

bifurkációjának irányát, és ezt az $a(0)$ számot a következô képlet alapján kaphatjuk meg:

$$
\begin{aligned}
a(0)= & \operatorname{Re}\left(\frac{e^{-i \theta_{0}} g_{21}}{2}\right)-\operatorname{Re}\left(\frac{\left(1-2 e^{i \theta_{0}}\right) e^{-2 i \theta_{0}}}{2\left(1-e^{i \theta_{0}}\right)} g_{20} g_{11}\right) \\
& -\frac{1}{2}\left|g_{11}\right|^{2}-\frac{1}{4}\left|g_{02}\right|^{2} .
\end{aligned}
$$

Ezt a formulát felhasználva kapjuk a következő invariáns kifejezést:

$$
\begin{aligned}
a(0)= & \frac{1}{2} \operatorname{Re}\left\{e ^ { - i \theta _ { 0 } } \left[\langle p, C(q, q, \bar{q})\rangle+2\left\langle p, B\left(q,(E-A)^{-1} B(q, \bar{q})\right)\right\rangle\right.\right. \\
& \left.\left.+\left\langle p, B\left(\bar{q},\left(e^{2 i \theta_{0}} E-A\right)^{-1} B(q, q)\right)\right\rangle\right]\right\} .
\end{aligned}
$$

Ennek az együtthatónak a segítségével láthatjuk be $n$ dimenziós $(n \geq 2)$ rendszerekre Neimark-Sacker-bifurkáció esetén a nemlineáris tag nemelfajulását.

\section{A 3.5. tétel bizonyítása}

Most az eljárás alapján kiszámítjuk az $a(0)$ értékét a (3.1) rendszerben. 
A 3.6. tétel (1) feltételének ellenőrzéséhez az $r^{\prime}(0)$ értéket numerikusan számítottuk, és a következôt kaptuk: $r^{\prime}(0)=-0,00217713$. (A transzverzalitás közvetlen igazolásához ábrázoltuk $r$ interpolációs függvényét, ld. 3.9. ábra.) A kritikus sajátértékek $0,561391+0,827552 i$ és $0,561391-0,827552 i$, vagyis nem negyedik vagy annál kisebb rendû egységgyökök, tehát a 3.6. tétel (2) feltétele is teljesül.

Ezután meghatározzuk az $A$ Jacobi-mátrix sajátértékeit és a (3.5)-ben, illetve (3.6)-ban bevezetett $q$ és $p$ sajátvektorokat:

$$
\begin{gathered}
q=(-0,67126-0,0108908 i ;-0,0793651-0,049971 i ; \\
0,0181909+0,0608618 i ; 0,732434+i) \\
p=(0,0134851-0,0321706 i ;-0,19597-0,00610824 i ; \\
0,97727 ;-0,0340428+0,0642307 i)
\end{gathered}
$$

Ezután kiszámítjuk a (3.8)-ban, illetve (3.9)-ben megadott $B$ és $C$ függvényeket. Itt csak $B_{1}$-et és $C_{1}$-et mutatjuk meg; a többi függvény ezekhez hasonló alakú.

$$
B_{1}(x, y)=\left(\begin{array}{l}
0,281071 x_{1} y_{1}+1,3569 x_{2} y_{1}-4,99837 x_{3} y_{1}+0,337012 x_{4} y_{1}+ \\
1,3569 x_{1} y_{2}-30,0461 x_{2} y_{2}+42,9415 x_{3} y_{2}-1,51484 x_{4} y_{2}- \\
4,99837 x_{1} y_{3}+42,9415 x_{2} y_{3}+208,644 x_{3} y_{3}+7,85539 x_{4} y_{3}+ \\
0,337012 x_{1} y_{4}-1,51484 x_{2} y_{4}+7,85539 x_{3} y_{4}-2,8086 x_{4} y_{4}
\end{array}\right)
$$




$$
\begin{gathered}
C_{1}(x, y, z)= \\
\left(\begin{array}{l}
0,413396 x_{1} y_{1} z_{1}+3,40342 x_{2} y_{1} z_{1}-13,5565 x_{3} y_{1} z_{1}+0,961551 x_{4} y_{1} z_{1}+ \\
3,40342 x_{1} y_{2} z_{1}+6,19157 x_{2} y_{2} z_{1}+28,8248 x_{3} y_{2} z_{1}-1,50999 x_{4} y_{2} z_{1}- \\
13,5565 x_{1} y_{3} z_{1}+28,8248 x_{2} y_{3} z_{1}-369,354 x_{3} y_{3} z_{1}+10,0174 x_{4} y_{3} z_{1}+ \\
0,961551 x_{1} y_{4} z_{1}-1,50999 x_{2} y_{4} z_{1}+10,0174 x_{3} y_{4} z_{1}+0,136465 x_{4} y_{4} z_{1}+ \\
3,40342 x_{1} y_{1} z_{2}+6,19157 x_{2} y_{1} z_{2}+28,8248 x_{3} y_{1} z_{2}-1,50999 x_{4} y_{1} z_{2}+ \\
6,19157 x_{1} y_{2} z_{2}-696,409 x_{2} y_{2} z_{2}+234,526 x_{3} y_{2} z_{2}-13,6853 x_{4} y_{2} z_{2}+ \\
28,8248 x_{1} y_{3} z_{2}+234,526 x_{2} y_{3} z_{2}+2845,51 x_{3} y_{3} z_{2}-41,4316 x_{4} y_{3} z_{2}- \\
1,50999 x_{1} y_{4} z_{2}-13,6853 x_{2} y_{4} z_{2}-41,4316 x_{3} y_{4} z_{2}-0,0275582 x_{4} y_{4} z_{2}- \\
13,5565 x_{1} y_{1} z_{3}+28,8248 x_{2} y_{1} z_{3}-369,354 x_{3} y_{1} z_{3}+10,0174 x_{4} y_{1} z_{3}+ \\
28,8248 x_{1} y_{2} z_{3}+234,526 x_{2} y_{2} z_{3}+2845,51 x_{3} y_{2} z_{3}-41,4316 x_{4} y_{2} z_{3}- \\
369,354 x_{1} y_{3} z_{3}+2845,51 x_{2} y_{3} z_{3}+8360,91 x_{3} y_{3} z_{3}+642,894 x_{4} y_{3} z_{3}+ \\
10,0174 x_{1} y_{4} z_{3}-41,4316 x_{2} y_{4} z_{3}+642,894 x_{3} y_{4} z_{3}+0,598556 x_{4} y_{4} z_{3}+ \\
0,961551 x_{1} y_{1} z_{4}-1,50999 x_{2} y_{1} z_{4}+10,0174 x_{3} y_{1} z_{4}+0,136465 x_{4} y_{1} z_{4}- \\
1,50999 x_{1} y_{2} z_{4}-13,6853 x_{2} y_{2} z_{4}-41,4316 x_{3} y_{2} z_{4}-0,0275582 x_{4} y_{2} z_{4}+ \\
10,0174 x_{1} y_{3} z_{4}-41,4316 x_{2} y_{3} z_{4}+642,894 x_{3} y_{3} z_{4}+0,598556 x_{4} y_{3} z_{4}+ \\
0,136465 x_{1} y_{4} z_{4}-0,0275582 x_{2} y_{4} z_{4}+0,598556 x_{3} y_{4} z_{4}-18,9188 x_{4} y_{4} z_{4}
\end{array}\right)
\end{gathered}
$$

E két függvény segítségével meghatározhatjuk az a(0)-ra vonatkozó (3.13) formulában szereplő skalárszorzatok értékeit.

Így azt kapjuk, hogy a (3.1) rendszerre a $p=139,455$ paraméterértéknél az $a(0)=-13,9966$, azaz nem 0 , így a rendszer nemelfajuló, tehát a megadott paraméterértéknél nemelfajuló Neimark-Sacker-bifurkáción megy keresztül. Mivel az $a(0)$ negatív, szuperkritikus Neimark-Sacker-bifurkáció történik, vagyis egy stabil fixpontból egy stabil invariáns zárt görbe bifurkálódik. 


\section{4. fejezet}

\section{Dinamikus rendszerek attraktorainak számítógépes vizsgálata}

Számos programcsomag is készült ugyan dinamikus rendszerek vizsgálatára, ezek közül a 2002-ben megjelent, Mathematicá-ban íródott Dynamica [13] programcsomag azonban nem ad lehetôséget az attraktorok és medencéik vizsgálatára, a Dynamics [18] programcsomag medencekirajzoló eljárása pedig pontatlanságokat eredményezhet, részben az algoritmus miatt, részben pedig amiatt, hogy az eljárás a képernyôt használja az adatok tárolására. Ez magasabb dimenziós rendszerek vizsgálatánál különösen hátrányos, hiszen ekkor az eljárás mindig csak a kétdimenziós vetület alapján számol. Ezenkívül, mivel a Dynamics DOS alatt fut, a legtöbb mai számítógépen már nem múködik.

Ezért szükség van egy olyan programra, amely dinamikus rendszerek attraktorait rajzolja ki, az eddigieknél pontosabb algoritmus szerint, és a mai számítógépeken is futtatható. 


\subsection{A Dynamics algoritmusa}

Az új algoritmus a Dynamics algoritmusának továbbfejlesztése, ezért elôször meg kell ismernünk a Dynamics medencerajzoló eljárását, a Basins and Attractors eljárást.

Az eljárás a képernyôt téglalapokra osztja és a téglalapokat páros, illetve páratlan számokkal jelzett színekkel színezi. A páros színek attraktorokat, a páratlanok pedig medencéket jelentenek. Az 1. szín a végtelen medencéjét jelöli, a $2 n$-edik színú attraktor medencéjét a program a $2 n+1$-edik színnel színezi.

Kezdetben minden téglalap színezetlen és az eljárás előrehaladtával mindegyik téglalap kap színt. Az eljárás kiválaszt egy színezetlen téglalapot és megvizsgálja a közepéból indított trajektóriát. E téglalap színét az határozza meg, hogy a belóle indított trajektória milyen, korábban már kiszínezett téglalapot érint.

Jelölje $C_{1}$ a legkisebb páros számot, amelyet még nem használtunk a színezésnél. A kiválasztott téglalapnak ideiglenesen a $C_{1}+1$ színt adjuk, és a téglalap közepén levô pontot elkezdjük iterálni. Amíg a trajektória színezetlen téglalapokban halad, e téglalapokat szintén $C_{1}+1$ színnel színezzük. Az iteráció folytatásával a trajektória vagy elér egy már színezett téglalapot, vagy divergál. A további színezésnél az eljárás a következô szabályokat alkalmazza:

(1) A trajektória divergál. Nem tudjuk pontosan ellenőrizni, hogy egy pont pályája valóban a végtelenbe tart-e, így akkor mondjuk, hogy egy trajektória divergál, ha elhagyja a képernyôt (vagyis a vizsgált térrészt) és megfelelố távolságra kerül tôle. Ekkor az összes, $C_{1}+1$ színú téglalapot 1 színưre színezzük át és az eljárás leáll az iterációval.

(2) A trajektória olyan téglalapon halad át, amelyet korábban már érintett és így $C_{1}+1$ színưre színezett. Ha egymás után bizonyos számú lépésen keresztül csak $C_{1}+1$ színú téglalapokban halad a trajektória, akkor az ezután érintett színezetlen vagy $C_{1}+1$ színú téglalapokat már $C_{1}$ színnel színezi. 
(3) Miközben $C_{1}+1$ színnel színezünk, a trajektória egy $C_{2}$ színú téglalapon halad át, ahol $C_{2}<C_{1}$, és $C_{2}$ páratlan. Ez azt jelenti, hogy találtunk egy másik trajektóriát, amellyel az aktuális trajektória együtt halad bizonyos számú lépésen át, és az algoritmus feltételezi, hogy ez a két trajektória ezután is közel marad egymáshoz és ugyanahhoz az attraktorhoz tart, így az eljárás leáll az iterációval és az összes $C_{1}+1$ színú téglalapot $C_{2}$ színúre színezzük.

(4) Miközben $C_{1}$ színnel színezünk, a trajektória egy $C_{2}$ színú téglalapokon halad keresztül bizonyos számú lépésen át, ahol $C_{2}$ páratlan, és $C_{2}<$ $C_{1}$. Ebben az esetben nem változtatunk semmit, az iteráció folytatódik, hiszen az attraktor közel lehet más attraktorok medencéjéhez.

(5) A trajektória egy $C_{3}$ színú téglalapon halad keresztül, ahol $C_{3}$ páros, és $C_{3}<C_{1}$. Az elôzô esethez hasonlóan ez azt jelenti, hogy találtunk egy másik trajektóriát, amely aktuális trajektóriánkkal bizonyos számú lépésen keresztül együtt halad. Ekkor az eljárás leáll az iterációval és minden $C_{1}$ és $C_{1}+1$ színû téglalapot $C_{3}+1$ színưre színezünk át.

Ha a trajektória számítása közben az (1), (3), (4) és (5) esetek egyike sem áll fenn, akkor mindenképpen a (2) eset áll fenn és végül eljutunk oda, hogy bizonyos számú iteráción keresztül sem színezetlen, sem $C_{1}+1$ színú téglalapot nem érintünk. Ez kaotikus attraktor esetén több ezer iterációt is megkívánhat. Ekkor az eljárás leáll az iterációval és egy újabb színezetlen téglalapot választ, amelyre ugyanezt végrehajtja.

\subsection{Az új algoritmus}

A Dynamics eljárásának számos hátránya van:

- Mivel minden számítást a kétdimenziós vetületen végez, előfordulhat, hogy különbözô attraktorokat összevon.

- A gridméretet a képernyő felbontása határozza meg, így a program nem tud elég pontosan számolni. 
- Az eljárás a felbontás téglalapjait színezi, így különbözô pályák, attraktorok, medencék nem lehetnek tetszólegesen közel egymáshoz.

- Az algoritmus nem a pályákat követi, csak a felbontás téglalapjainak színezésén alapul és felteszi, hogy ha azonos színú téglalapokban haladunk, akkor egy másik pályát követünk, de ez nem feltétlenül igaz.

Új algoritmusunkkal megpróbáljuk kijavítani ezeket a hibákat.

Legyen $n$ a vizsgált rendszer dimenziója. A vizsgált $n$ dimenziós téglatestet felosztjuk egyenlő részekre és mindegyik téglatest középpontjából indítunk egy trajektóriát. A 2.4. példában definiált diszkrét dinamikus rendszer esetében ez az $F$ leképezés iterációját jelenti, folytonos dinamikus rendszerek (vagyis differenciálegyenletek) esetén pedig a rendszer diszkretizáltját vizsgáljuk.

Ezt a következóképpen definiáljuk:

4.1. Definíció. Tekintsük a 2.3. példában szereplő közönséges differenciálegyenlet $x\left(t, t_{0}, x_{0}\right)$ megoldását. Definiáljuk a következö leképezést:

$$
\begin{gathered}
F: \mathbb{R}^{n} \rightarrow \mathbb{R}^{n} \\
x_{n+1}=F\left(x_{n}\right)=x\left(1,0, x_{n}\right)
\end{gathered}
$$

Ekkor egy differenciaegyenletet kapunk, amely által indukált diszkrét dinamikus rendszert a differenciálegyenlet által indukált folytonos dinamikus rendszer diszkretizáltjának nevezzük.

Folytonos rendszerek esetén tehát először ki kell számítanunk az adott pontból indított megoldást, és ezt kell vennünk a $t=1$ pillanatban.

Az iteráció során minden lépés után eltároljuk az aktuális pontot és azt, hogy a felosztás mely téglatestébe esik. A téglalapok színezésére számokat használunk. A divergáló trajektóriákat ugyanúgy kezeljük, mint a Dynamics eljárása: ha egy trajektória elegendôen távol kerül a vizsgált tartománytól, azt mondjuk, hogy a pálya divergál, és a végtelen medencéjének színét kapja. 
Amennyiben ez nem teljesül, azaz a pályánk következô pontja a vizsgált tartományba esik, megvizsgáljuk azokat a pontokat, amelyek közel vannak az aktuális ponthoz, vagyis azokat, amelyek a pontot körülvevô $3^{n}$ darab téglatest valamelyikébe esnek.

Ha ezek között nincs olyan pont, amely bizonyos számú - nevezzük ezt a számot követési számnak - lépésen keresztül közel marad az aktuális trajektóriához, akkor folytatjuk az iterációt és újra megvizsgáljuk a közeli pontokat. Ha viszont találunk olyan pontot, amelynek iteráltjai bizonyos számú lépésen keresztül közel maradnak az aktuális trajektória megfelelő pontjához (vagyis szomszédos téglatestekbe vagy ugyanabba a téglatestbe esnek), akkor megállunk az iterációval és színt adunk az aktuális trajektóriának attól függően, hogy a közeli pont melyik trajektóriához tartozik:

(1) Ha az aktuális trajektória pontja, akkor ennek a trajektóriának a legkisebb, még nem használt páratlan színt adjuk, és eltároljuk, hogy melyik volt az a pont, amelyikhez elôször visszatértünk: ettől a ponttól kezdve fogjuk a trajektória pontjait az attraktor színével színezni. Annak érdekében, hogy ugyanazon attraktor különbözô, egymástól távol levố részeit ne különbözô attraktorokként kezeljük, minden újonnan megtalált attraktort megvizsgálunk: összehasonlítjuk a korábban talált attraktorokkal. Amennyiben elegendôen sok egymáshoz közeli pontjuk van, leellenôrizzük, hogy ezek a pontok közel maradnak-e egymáshoz bizonyos számú iteráción keresztül. Ha van ilyen, korábban megtalált attraktor, akkor az aktuális trajektóriának e korábban talált attraktor és medencéje színét adjuk.

(2) Ha nem az aktuális pálya pontja, akkor az aktuális trajektóriának a közeli pont trajektóriájának színét adjuk.

Ezután a pontosabb ábrázolás kedvéért az attraktorban haladva még bizonyos számú pontot kiszámítunk.

Az eljárás előnye, hogy jóval pontosabb, mint a korábbi algoritmus. Ezt az biztosítja, hogy csak olyan pontokat vizsgálunk, amelyek valóban közel esnek az éppen vizsgált trajektóriához, valamint az, hogy csak akkor színezünk át egy trajektóriát egy másik trajektória színére, ha a két pálya valóban 
együtt halad több iteráción keresztül. A beosztás finomításával és a követési szám növelésével tetszóleges pontosság elérhetô. A Dynamics algoritmusa a felosztás minden téglalapjának csak egy színt ad, noha egy téglalapon több trajektória is áthaladhat. Az új algoritmus viszont egy téglalapon belül több színnel is színezhet, ami pontosabb ábrázolást tesz lehetôvé. Az új algoritmus elônye az is, hogy a magasabb dimenziós rendszereket is pontosan vizsgálja.

\subsection{A program}

Az algoritmus alapján készült programunk első változata Mathematicá-ban készült, a könnyebb használhatóság és a nagyobb sebesség érdekében Visual $C++$ nyelvre írtuk át. Az új program számos, a dinamikus rendszerek vizsgálatát megkönnyítô funkcióval rendelkezik. A program indítása után megadjuk a rendszer dimenzióját, a gridméretet, a „követési számot”, valamint a vizsgált térrész kezdô- és végpontjainak koordinátáit. Az egyenleteket egy beépített elemzô segítségével értelmezi a program. A számítás befejeztével megjelenik az ábra. Tetszőleges kétdimenziós vetületet tudunk ábrázolni, kiválaszthatjuk, hogy mely attraktorokat és medencéket szeretnénk megjeleníteni, az egér segítségével tudjuk mozgatni és nagyítani az ábrát. A képet két formátumban - egy speciális, a számítás eredményeit megőrző formátumban, illetve EPS fájlként - tudjuk menteni.

\subsection{Példák}

\subsubsection{Az Hénon-leképezés}

A 4.1. ábrán a híres Hénon-leképezés [18] különös attraktora látható.

$$
\begin{aligned}
x_{1}^{\prime} & =1-x_{1}^{2}+0,475 x_{2} \\
x_{2}^{\prime} & =x_{1}
\end{aligned}
$$




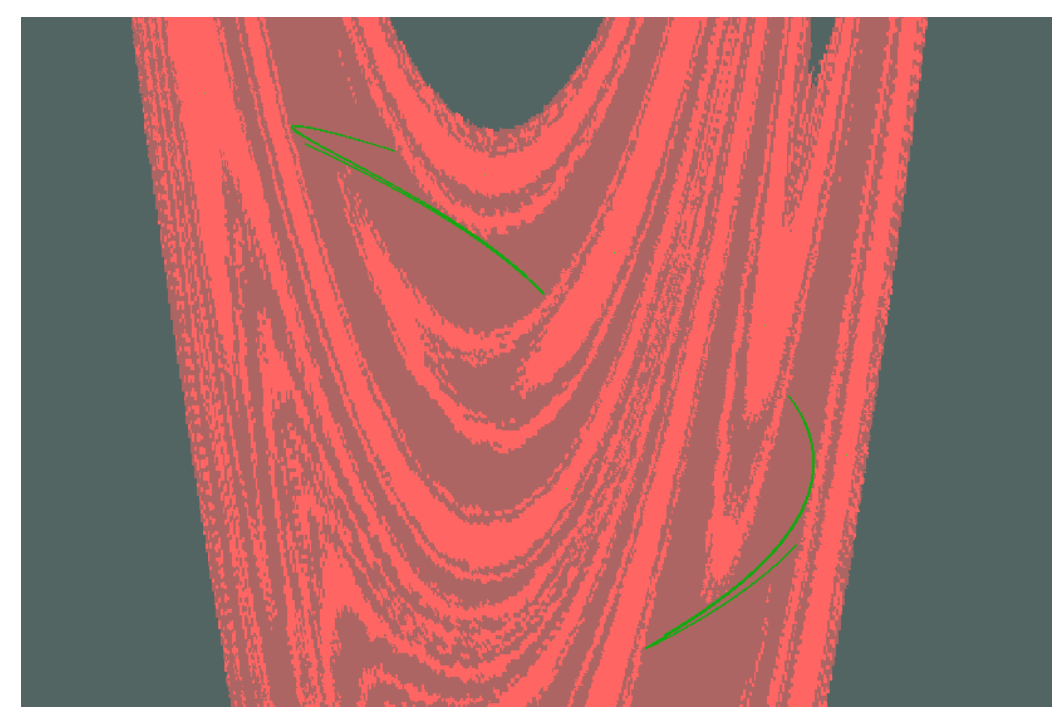

4.1. ábra. Az Hénon-leképezés

\subsubsection{A Bogdanov-leképezés}

A 4.2. ábrán a Bogdanov-leképezés attraktorai és azok medencéi láthatók.

$$
\begin{aligned}
& x_{1}^{\prime}=x_{1}+1,0025 x_{2}+1,44 x_{1}\left(x_{1}-1\right)-0,1 x_{1} x_{2} \\
& x_{2}^{\prime}=1,0025 x_{2}+1,44 x_{1}\left(x_{1}-1\right)-0,1 x_{1} x_{2}
\end{aligned}
$$

Djellit és Boukemara [8] a Bogdanov-leképezés attraktorait és medencéit pontatlanul adták meg, és erre a rendszerre a Dynamics is pontatlan ábrát ad (4.3. ábra). A programunk által készített rajz (4.2. ábra) pontosan mutatja az attraktorokat és medencéiket: az origó körüli öt világoszöld pontból álló attraktor medencéje a Dynamics ábrája szerint egy öt szigetból álló halmaz, valójában azonban - ahogy azt a programunk által készített ábra mutatja a szigetek által közrefogott részben is sûrü az attraktor medencéje. E terület a Dynamics rajzán az öt pontból álló attraktor körüli sötétzöld zárt görbe medencéjéhez tartozik.

Mivel algoritmusunk a pontok és nem a felbontás téglalapjai alapján szá- 


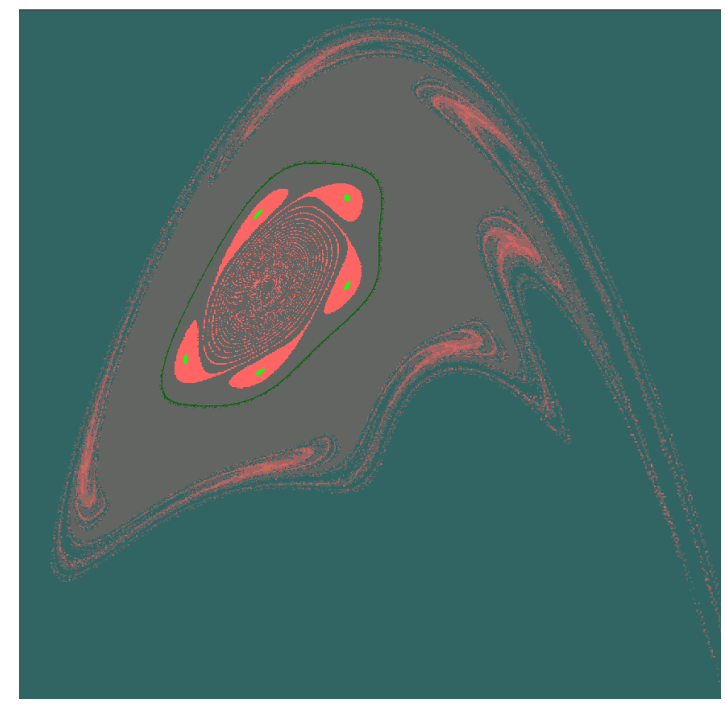

4.2. ábra. A Bogdanov-leképezés

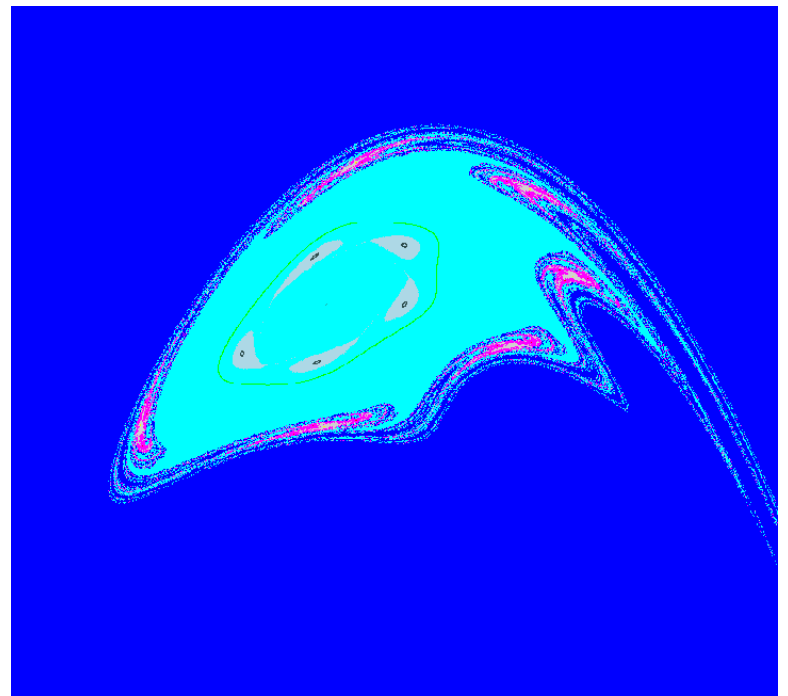

4.3. ábra. A Bogdanov-leképezés (Dynamics) 


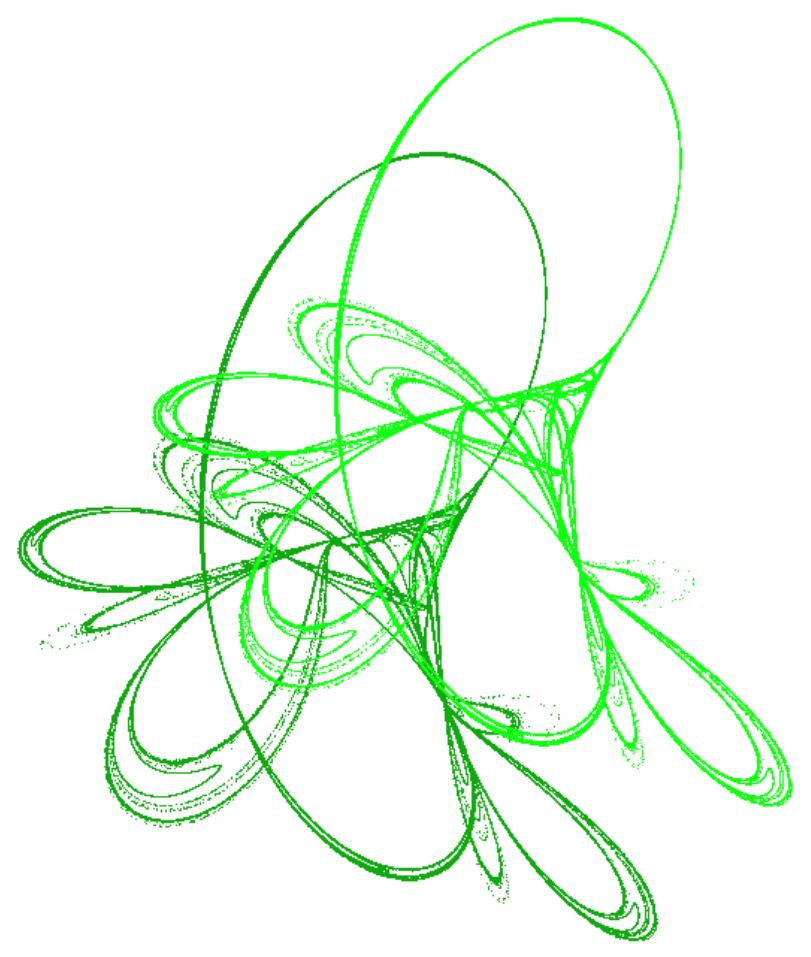

4.4. ábra. Háromdimenziós Tinkerbell-leképezés

mol, felismeri, hogy egy téglalapba különböző medencék pontjai is esnek.

\subsubsection{Háromdimenziós Tinkerbell-leképezés}

$$
\begin{aligned}
x_{1}^{\prime} & =x_{1}^{2}-x_{2}^{2}+0,9 x_{1}+0,6013 x_{2} \\
x_{2}^{\prime} & =2 x_{1} x_{2}+2 x_{1}+0,5 x_{2} \\
x_{3}^{\prime} & =\frac{2 x_{3}}{1+16 x_{3}^{2}}
\end{aligned}
$$

Ez a példa a kétdimenziós vetületek használatának veszélyét mutatja: a Dynamics a fenti rendszernek [18] csak egy attraktorát találja meg; valójában két attraktor van, amelyeknek ugyanaz a kétdimenziós vetülete. Programunk mindkét attraktort megtalálja. 

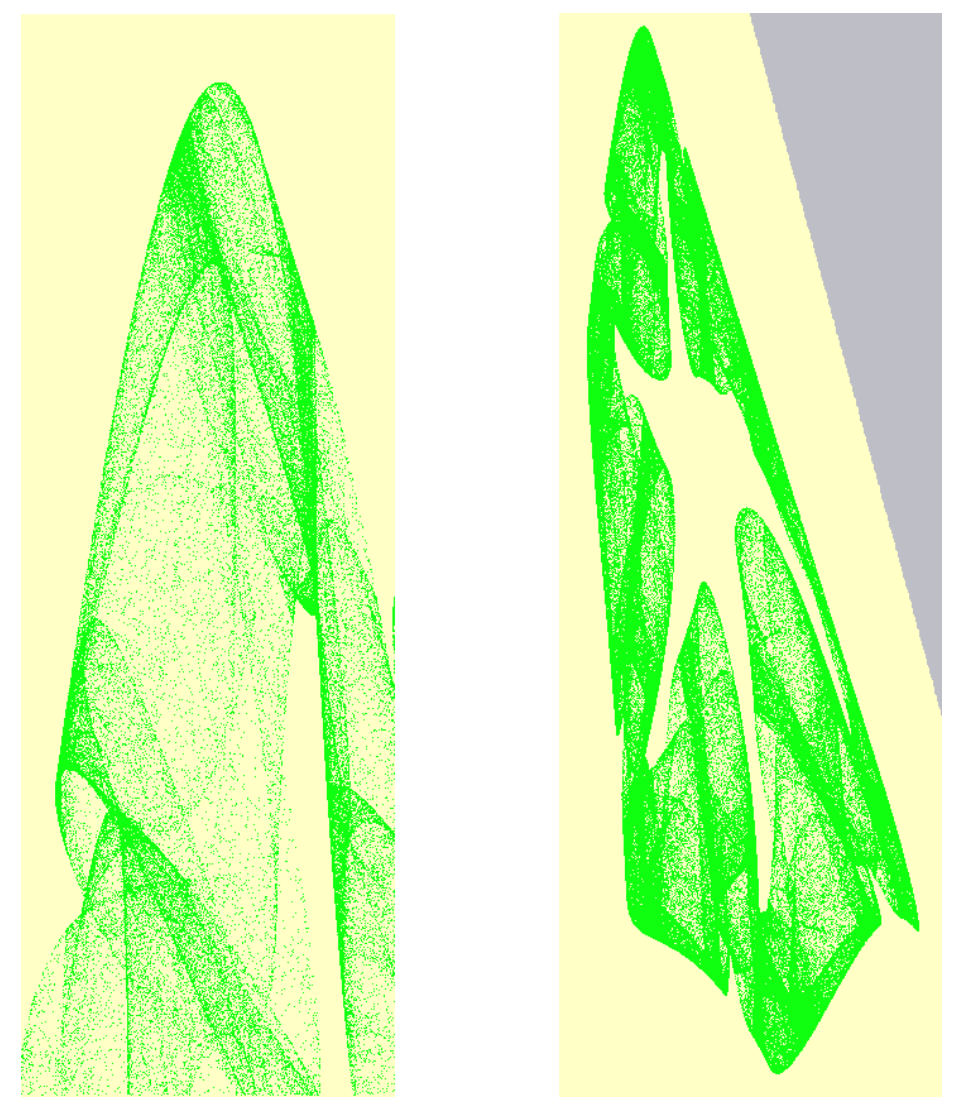

4.5. ábra. Maynard Smith ragadozó-zsákmány modellje

\subsubsection{Diszkrét ragadozó-zsákmány modell (Maynard Smith)}

A 4.5. ábrán az alábbi diszkrét ragadozó-zsákmány modell (Maynard Smith [12]) attraktorának egy része, illetve a teljes attraktor látható.

$$
\begin{aligned}
& x_{1}^{\prime}=3,6545 x_{1}\left(1-x_{1}\right)-x_{1} x_{2} \\
& x_{2}^{\prime}=\frac{1}{0,31} x_{1} x_{2}
\end{aligned}
$$

Amennyiben csak az attraktor egy részét tartalmazó területet vizsgáljuk, ugyanezekkel a kezdô- és végpontokkal a Dynamics nem találja meg az attraktort. 


\section{5. fejezet}

\section{Egy nemautonóm populációdinamikai modell eventuális stabilitási tulajdonságai}

\subsection{A modell}

A disszertáció harmadik részében egy populációdinamikai modellel foglalkozunk. A modell a Tanganyika-tóban élő különleges halfajok (egy ragadozó és egy növényevô) és a növényevôk táplálékául szolgáló növényzet mennyiségének változását írja le. A Tanganyika-tóban - a világon egyedülálló módon aszimmetrikus fejú ragadozó halak élnek: a halak egy részének bal felé, másik részüknek jobb felé áll a szája. A balra álló szájú halak többnyire balról, a jobb felé álló szájúak pedig jobbról támadják meg áldozatukat. Megfigyelték, hogy a zsákmányhalak megpróbálnak alkalmazkodni a jobbról, illetve balról érkezô támadások eloszlásához: egy részük elsôsorban a jobbról érkezô támadásokra figyel, más részük pedig a balról érkezőkre. Stratégiájuk meglehetôsen merev: egy adott példány egész életében ugyanazt a stratégiát követi. 
A fent leírt jelenség számos, a növények, valamint a növényevô és ragadozó halak fejlődését leíró matematikai modell megalkotását teszi lehetôvé.

A továbbiakban $\mathcal{I}$ és $\mathcal{K}$ két (véges) indexhalmaz, melyek a ragadozók és a növényevôk különbözô csoportjait jelölik. A fentiekben leírt esetben mindkét halmaz kételemú: a ragadozók két csoportja a jobbra, illetve a balra álló szájú halak csoportja, a zsákmányhalaké pedig a jobbra, illetve a balra figyelő halak csoportja.

Technikai okok miatt nem korlátozzuk a különbözô csoportok számát. A következókben $n_{i}=n_{i}(t)$ jelöli az $i \in \mathcal{I}$ típusú növényevô halak számát a $t$ idôpillanatban. Hasonlóan, $m_{k}=m_{k}(t)$ jelöli a $k \in \mathcal{K}$ csoportba tartozó ragadozó halak számát a $t$ időben.

A növények, a növényevô halak és a ragadozók által alkotott táplálékláncot a Nap látja el energiával. Feltesszük, hogy az energia állandó intenzitással áramlik, valamint azt is feltesszük, hogy a növények összmennyiségének a napenergia hatására történő növekedése időegységenként $C$. (Ugyanezt a modellt kapjuk, ha azt tesszük fel, hogy a táplálékot kívülrôl juttatjuk a tóba egyenlő intenzitással.) A növényevô halak a növényeket fogyasztják: feltesszük, hogy egy $w$ súlyú egyed $\alpha(w)$ mennyiséget eszik meg időegység alatt.

Feltesszük, hogy mindegyik $i \in \mathcal{I}$ csoport azonos $w_{i}=w_{i}(t)$ súlyú növényevô egyedekből áll, valamint hogy a ragadozók tetszőleges $k \in \mathcal{K}$ csoportjába azonos $u_{k}=u_{k}(t)$ súlyú egyedek tartoznak.

Jelölje $K=K(t)$ a növényzet összmennyiségét a $t$ idôpontban. A növényekre és a növényevố halakra eddig megadott feltételeinket a következô egyenlettel írhatjuk le:

$$
\dot{K}=C-\sum_{i} n_{i} \alpha\left(w_{i}\right) K
$$

Feltesszük, hogy az egyéves fejlődési periódus alatt a ragadozó halak nem pusztulnak, azaz $m_{k}(t)$ konstans, a növényevôk száma viszont csökken, hiszen a ragadozók táplálékául szolgálnak.

Feltesszük, hogy a különbözô csoportok eloszlása homogén a tóban, a 
támadások száma pedig a súrúségükkel arányos, vagyis egységnyi idô alatt a $k$ típusú ragadozók $\rho n_{i} m_{k}$ alkalommal támadják meg az $i$ típusú növényevôket valamilyen $\rho$ konstanssal. Feltesszük, hogy egy ilyen támadás során $w$ súlyú, $i$ típusú növényevôt $\beta^{(i, k)}(w, u)$ valószínüséggel eszik meg egy $u$ súlyú, $k$ típusú ragadozó. Tehát

$$
\dot{n}_{i}=-\sum_{k} \rho \beta^{(i, k)}\left(w_{i}, u_{k}\right) n_{i} m_{k}
$$

Jelölje $\gamma(e, w)$ azt a súlyt, amellyel egy $w$ súlyú növényevô gyarapodik $e$ mennyiségú növény elfogyasztásával. A súlyt, amelyet egy növényevő egységnyi idő alatt evés nélkül veszít, $\tilde{\gamma}(w)$-vel jelöljük. Így

$$
\dot{w}_{i}=\gamma\left(\alpha\left(w_{i}\right) K, w_{i}\right)-\tilde{\gamma}\left(w_{i}\right)
$$

Mivel feltettük, hogy az egyéves fejlődési periódusban a ragadozók nem pusztulnak (csak a súlyuk változik):

$$
\dot{m}_{k}=0 \text {. }
$$

Jelölje $\delta(e, u)$ azt a súlyt, amellyel egy $u$ súlyú ragadozó gyarapodik e mennyiségú zsákmány elfogyasztásával. A súlyt, amelyet egy ragadozó egységnyi idő alatt evés nélkül veszít, $\tilde{\delta}(w)$-vel jelöljük. Így

$$
\dot{u}_{k}=\delta\left(\sum_{i} \rho \beta^{(i, k)}\left(w_{i}, u_{k}\right) w_{i} n_{i} m_{k}, u_{k}\right)-\tilde{\delta}\left(u_{k}\right)
$$

\subsection{A modell egyszerüsítése}

Feltesszük, hogy a következő függvények lineárisak: $\alpha(w)=\alpha w, \gamma(e, w)=\gamma e$, $\delta(e, u)=\delta e, \beta^{(i, k)}(w, u) \equiv \beta^{(i, k)}, \tilde{\gamma}(w)=\tilde{\gamma} w$ és $\delta \tilde{(u)}=\tilde{\delta} u$. Így az egyenleteink 
a következô alakot öltik:

$$
\begin{aligned}
\dot{K} & =C-\sum_{i} n_{i} \alpha w_{i} K, \\
\dot{n}_{i} & =-\sum_{k} \beta^{(i, k)} n_{i} m_{k} \rho, \\
\dot{w}_{i} & =\gamma \alpha w_{i} K-\tilde{\gamma} w_{i}, \\
\dot{u}_{k} & =\delta \rho \sum_{i} \beta^{(i, k)} w_{i} n_{i} m_{k}-\tilde{\delta} u_{k} .
\end{aligned}
$$

Vezessük be az $x_{i}:=n_{i} w_{i}$ és $y_{k}=m_{k} u_{k}$ változókat a növényevók, illetve a ragadozók összsúlyának jelölésére. Az új változókkal a következô egyenleteket kapjuk:

$$
\begin{aligned}
\dot{x}_{i} & =\dot{n}_{i} w_{i}+n_{i} \dot{w}_{i}= \\
& =-\sum_{k} \beta^{(i, k)} n_{i} m_{k} \rho w_{i}+n_{i} \gamma \alpha w_{i} K-n_{i} \gamma w_{i}= \\
& =\left[\alpha \gamma K-\tilde{\gamma}-\rho \sum_{k} \beta^{(i, k)} m_{k}\right] x_{i}
\end{aligned}
$$

és

$$
\begin{aligned}
\dot{y}_{k} & =m_{k} \dot{u}_{k}= \\
& =m_{k}^{2} \delta \rho \sum_{i} \beta^{(i, k)} w_{i} n_{i}-m_{k} \tilde{\delta} u_{k} \\
& =m_{k}^{2} \delta \rho \sum_{i} \beta^{(i, k)} x_{i}-\tilde{\delta} y_{k} .
\end{aligned}
$$

A következôkben csak a növények és a növényevôk fejlődésével foglalkozunk. Ha bevezetjük a $\tilde{\beta}^{i}=\sum_{k} \rho \beta^{(i, k)} m_{k}$ jelölést, a következô rendszert kapjuk:

$$
\begin{aligned}
\dot{K} & =C-\alpha\left(\sum_{i} x_{i}\right) K, \\
\dot{x}_{i} & =\left[\alpha \gamma K-\left(\tilde{\gamma}+\tilde{\beta}^{i}\right)\right] x_{i} .
\end{aligned}
$$


A második egyenletból kapjuk, hogy

$$
x_{i}(t)=x_{i}(0) \exp \left(-\left(\tilde{\gamma}+\tilde{\beta}^{i}\right) t\right) \exp \left(\alpha \gamma \int_{0}^{t} K\right)
$$

és

$$
\dot{K}=C-\alpha\left(\sum_{i} x_{i}(0) \exp \left(-\left(\tilde{\gamma}+\tilde{\beta}^{i}\right) t\right)\right) K \exp \left(\alpha \gamma \int_{0}^{t} K\right)
$$

Ha bevezetjük az

$$
E:=\exp \left(\alpha \gamma \int_{0}^{t} K\right)
$$

új változót, a következő egyenleteket kapjuk:

$$
\dot{E}=\exp \left(\alpha \gamma \int_{0}^{t} K\right) \alpha \gamma K=\alpha \gamma E K
$$

és

$$
\dot{K}=C-\alpha\left(\sum_{i} x_{i}(0) \exp \left(-\left(\tilde{\gamma}+\tilde{\beta}^{i}\right) t\right)\right) E K .
$$

Vezessük be az

$$
A(t)=\alpha \sum_{i} x_{i}(0) \exp \left(-\left(\tilde{\gamma}+\tilde{\beta}^{i}\right) t\right)
$$

függvényt. Rendszerünk a következô alakot ölti:

$$
\begin{aligned}
\dot{K} & =C-A E K, \\
\dot{E} & =\alpha \gamma E K .
\end{aligned}
$$

Az $\alpha \gamma$ konstans kiküszöbölésére bevezetjük az új $\hat{t}$ idôváltozót úgy, hogy

$$
t=\hat{\lambda} \hat{t}, \quad L(\hat{t}):=K(\hat{\lambda} \hat{t}), \quad F(\hat{t}):=E(\hat{\lambda} \hat{t}) .
$$


Legyen $\hat{\lambda}:=1 / \alpha \gamma$. Így a következôt kapjuk:

$$
\begin{aligned}
\frac{d}{d \hat{t}} L & =\hat{C}-\hat{A}(\hat{t}) F(\hat{t}) L(\hat{t}), \\
\frac{d}{d \hat{t}} F & =F(\hat{t}) L(\hat{t}),
\end{aligned}
$$

ahol

$$
\begin{gathered}
\hat{C}=\frac{C}{\alpha \gamma}, \hat{A}(\hat{t})=\frac{1}{\gamma} \sum_{i} x_{i}(0) \exp \left(-\frac{\tilde{\gamma}+\tilde{\beta}^{i}}{\alpha \gamma} \hat{t}\right)=\sum_{i} \mu_{i} \exp \left(-\lambda_{i} t\right), \\
\mu_{i}:=\frac{x_{i}(0)}{\gamma}, \lambda_{i}:=\frac{\tilde{\gamma}+\tilde{\beta}^{i}}{\alpha \gamma} .
\end{gathered}
$$

Az előbbi egyenletekból a kalapok elhagyásával a

$$
\begin{aligned}
\dot{L} & =C-A F L, \\
\dot{F} & =F L
\end{aligned}
$$

rendszert kapjuk. A $G(t)=A(t) F(t)$ jelölés bevezetésével

$$
\dot{G}(t)=\dot{A}(t) F(t)+A(t) \dot{F}(t)=\frac{\dot{A}(t)}{A(t)} A(t) F(t)+A(t) F(t) .
$$

Vezessük be a

$$
\lambda(t):=-\frac{\dot{A}(t)}{A(t)}
$$

függvényt. Ekkor

$$
\begin{aligned}
\dot{L} & =C-L G, \\
\dot{G} & =(L-\lambda(t)) G
\end{aligned}
$$

a

$$
Q:=\{(L, G): L \geq 0, G>0\}
$$

síknegyedben. Egyszerúen látható, hogy $Q$ invariáns az (5.4) egyenletre.

Modellünkben a különbözô típusú növényevôk össztömegeinek, $x_{i}(t)$-nek 
és a növények mennyiségének, $L(t)$-nek (ld. (5.2)) dinamikáját az (5.1) és az (5.4) egyenletek adják meg. Mint általában a populációdinamikában, e változók hosszú távú viselkedésére vagyunk kíváncsiak. Az elsô lépés, hogy meghatározzuk az (5.4) rendszer stabilitási tulajdonságait $L$-re nézve, amit azután felhasználhatunk az $x_{i}$ vizsgálatára az (5.1) egyenlet segítségével. Megmutatjuk, hogy $L(t)$ bizonyos értelemben egyenletesen tart $\lambda^{*}$-hoz $(t \rightarrow \infty)$, ahol $\lambda^{*}:=\lim _{t \rightarrow \infty} \lambda(t)$.

\subsection{A stabilitási tétel}

Fố tételünk kimondásához szükségünk van néhány stabilitáselméleti definícióra [15], [22]. Tekintsük az alábbi differenciálegyenlet-rendszert:

$$
\dot{x}=f(t, x)
$$

ahol $f: \mathbb{R}^{+} \times \Omega \rightarrow \mathbb{R}^{n}$, ahol $\mathbb{R}^{+}=[0, \infty)$ és $\Omega$ az $\mathbb{R}^{n}$ nyitott részhalmaza; $0 \in \Omega$. Legyen $\|\cdot\|$ tetszóleges norma $\mathbb{R}^{n}$-ben. Tegyük fel, hogy minden $t_{0} \geq 0$-ra és $x_{0} \in \Omega$-ra az (5.5) egyenletnek létezik egyetlen $x(t)=x\left(t ; t_{0}, x_{0}\right)$ megoldása, amely teljesíti az $x\left(t_{0} ; t_{0}, x_{0}\right)=x_{0}$ kezdeti feltételt.

5.1. Definíció. $x=0$ eventuálisan stabil pontja (5.5)-nek, ha tetszóleges $\varepsilon>0$-ra és $t_{0} \geq 0$-ra létezik $S(\varepsilon) \geq 0$ és $\delta\left(\varepsilon, t_{0}\right)>0$ úgy, hogy $t_{0} \geq S(\varepsilon)$-ból és $\left\|x_{0}\right\|<\delta\left(\varepsilon, t_{0}\right)$-ból következik, hogy $\left\|x\left(t ; t_{0}, x_{0}\right)\right\|<\varepsilon$ minden $t \geq t_{0}$-ra. Ha $\delta=\delta(\varepsilon)>0$ független $t_{0}$-tól, akkor az eventuális stabilitás egyenletes.

5.2. Definíció. $x=0$ globálisan eventuálisan aszimptotikusan stabil pontja (5.5)-nek, ha $x=0$ eventuálisan stabil, és minden megoldás nullához tart, ha $t \rightarrow \infty$.

5.3. Definíció. $x=0$ globálisan eventuálisan kvázi-egyenletesen aszimptotikusan stabil pontja (5.5)-nek, ha bármely kompakt $\Gamma \subset \Omega$ halmazra és minden $\gamma>0$-ra létezik $S(\Gamma, \gamma)$ és $T(\Gamma, \gamma)>0$ úgy, hogy ha $x_{0} \in \Gamma, t_{0} \geq S(\Gamma, \gamma)$ és $t \geq t_{0}+T(\Gamma, \gamma)$, akkor $\left\|x\left(t ; t_{0}, x_{0}\right)\right\|<\gamma$. 
5.4. Definíció. $x=0$ globálisan eventuálisan egyenletesen aszimptotikusan stabil pontja (5.5)-nek, ha eventuálisan egyenletesen stabil és globálisan kváziegyenletesen aszimptotikusan stabil.

Legyen $\lambda^{*}:=\min \left\{\lambda_{i}: i \in \mathcal{I}\right\}$. A 5.9. lemmában megmutatjuk, hogy

$$
\lim _{t \rightarrow \infty} \lambda(t)=\lambda^{*}
$$

Ezek után kimondhatjuk tételünket:

5.5. Tétel. $\left(\lambda^{*}, C / \lambda^{*}\right)$ globálisan eventálisan egyenletesen aszimptotikusan stabil pontja (5.4)-nek.

A tétel bizonyításához szükségünk lesz néhány fogalomra és egy egyszerú tényre a határegyenletek elméletéból.

Az $x^{*} \in \bar{\Omega}$ pontot az (5.5) egyenlet $x$ megoldása pozitív határpontjának nevezzük, ha létezik olyan $\left\{t_{j}\right\}$ sorozat, amelyre $t_{j} \rightarrow \infty$ és $x\left(t_{j}\right) \rightarrow x^{*}$ teljesül $(j \rightarrow \infty)$. Az $x$ pozitív határpontjainak halmazát $x$ pozitív határhalmazának nevezzük és $\Lambda^{+}(x)$-szel jelöljük.

Az $f: \mathbb{R}^{+} \times \Omega \rightarrow \mathbb{R}^{n}$ függvény $a>0$-val vett eltoltja: $f_{a}(t, x):=$ $f(t+a, x) . \mathrm{Az} f$ függvényt aszimptotikusan autonómnak nevezzük, ha létezik olyan $f^{*}: \Omega \rightarrow \mathbb{R}^{n}$ függvény, amelyre $f_{a}(t, x) \rightarrow f^{*}(x)(a \rightarrow \infty)$ egyenletesen $\mathbb{R}^{+} \times \Omega$ minden kompakt részhalmazán. Az $f^{*}$ függvényt határfüggvénynek, az $\dot{x}=f^{*}(x)$ egyenletet pedig határegyenletnek nevezzük.

Legyen $f(t, x)$ aszimptotikusan autonóm függvény. Az $F \subset \Omega$ halmaz félig invariáns az (5.5) egyenletre nézve, ha minden $\left(t_{0}, x_{0}\right) \in \mathbb{R}^{+} \times F$-ra van legalább egy nem folytatható $x^{*}:(\alpha, \omega) \rightarrow \mathbb{R}^{n}$ megoldása az $\dot{x}=f^{*}(x)$ határegyenletnek $x^{*}\left(t_{0}\right)=x_{0}$-ra úgy, hogy $x^{*}(t) \in F$ minden $t \in(\alpha, \omega)$-ra.

5.6. Tétel (félig invariancia [19]). Tegyük fel, hogy $f$ aszimptotikusan autonóm. Ekkor (5.5) tetszóleges $x$ megoldására $a \Lambda^{+}(x) \cap \Omega$ határhalmaz félig invariáns.

Az 5.5. tétel bizonyításának lépései: 
1. Belátjuk, hogy az

$$
\begin{aligned}
\dot{L} & =C-L G, \\
\dot{G} & =\left(L-\lambda^{*}\right) G
\end{aligned}
$$

határegyenlet $\left(\lambda^{*}, C / \lambda^{*}\right)$ egyensúlyi helyzete globálisan aszimptotikusan stabil. Először linearizáljuk a rendszert a (lokális) aszimptotikus stabilitás igazolásához, majd konstruálunk egy Ljapunov-függvényt, és a LaSalle-féle invarianciaelv alkalmazásával igazoljuk, hogy az egyensúlyi helyzet globálisan aszimptotikusan stabil.

2. Belátjuk, hogy $\left(\lambda^{*}, C / \lambda^{*}\right)$ eventuálisan egyenletesen stabil pontja az eredeti nemautonóm (5.4) egyenletnek.

3. Felhasználva az eventuális egyenletes stabilitást és a félig invarianciáról szóló tételt, bebizonyítjuk, hogy $\left(\lambda^{*}, C / \lambda^{*}\right)$ globálisan eventuálisan aszimptotikusan stabil pontja (5.4)-nek.

4. Felhasználva az egyenletes stabilitást és a Ljapunov-függvény deriváltjának struktúráját, bebizonyítjuk, hogy $\left(\lambda^{*}, C / \lambda^{*}\right)$ globálisan eventuálisan kvázi-egyenletesen aszimptotikusan stabil.

Az exponenciális stabilitás rendkívül fontos az alkalmazásokban (pl. az irányításelméletben). Lineáris rendszerek esetében az exponenciális stabilitás ekvivalens az egyenletes aszimptotikus stabilitással, így ez utóbbit tekinthetjük az exponenciális stabilitás nemlineáris rendszerekre való általánosításának. Fő tételünket ezért mondtuk ki egyenletes aszimptotikus stabilitásra.

\subsection{Bevezető jelölések és lemmák}

5.7. Lemma. $A z$ (5.6) határegyenlet $\left(\lambda^{*}, C / \lambda^{*}\right)$ egyensúlyi helyzete aszimptotikusan stabil. 
Bizonyítás. Az $\ell=L-\lambda^{*}, g=G-C \lambda^{*}$ transzformációk az egyensúlyi helyzetet az origóba viszik, és a következô rendszert kapjuk:

$$
\begin{aligned}
\dot{\ell} & =-\frac{C}{\lambda^{*}} \ell-\lambda^{*} g-\ell g, \\
\dot{g} & =\frac{C}{\lambda^{*}} \ell+\ell g .
\end{aligned}
$$

A linearizált egyenlet Jacobi-mátrixának sajátértékei

$$
-\frac{C}{2 \lambda^{*}} \pm \sqrt{\left(\frac{C}{2 \lambda^{*}}\right)-C}
$$

Mivel $C>0$, a $(0,0)$ egyensúlyi helyzet aszimptotikusan stabil. Abban az esetben, ha $\lambda^{*}>\sqrt{C} / 2$, a megoldások oszcillálnak; ha $\lambda^{*}<\sqrt{C} / 2$, a megoldások nem oszcillálnak.

5.8. Lemma. $A z$ (5.6) határegyenlet $\left(\lambda^{*}, C / \lambda^{*}\right)$ egyensúlyi helyzete globálisan aszimptotikusan stabil a $Q$ siknegyedben.

Bizonyitás. Definiáljuk a

$$
V(L, G)=\frac{1}{2}\left(L-\lambda^{*}\right)^{2}-C \ln G+\lambda^{*} G-C+C \ln \frac{C}{\lambda^{*}}
$$

Ljapunov-függvényt az $R:=\{(L, G): L \in \mathbb{R}, G>0\}$ halmazon. Megmutatjuk, hogy $V$ pozitív definit. Írjuk fel a $V$ függvényt

$$
V(L, G)=\frac{1}{2}\left(L-\lambda^{*}\right)^{2}+\lambda^{*}\left\{\left(G-\frac{C}{\lambda^{*}}\right)-\frac{C}{\lambda^{*}}\left[\ln G-\ln \frac{C}{\lambda^{*}}\right]\right\}
$$

alakban, és vezessük be a

$$
h(x):=(x-a)-a[\ln x-\ln a] \quad(a>0 ; x>0)
$$

függvényt. Mivel

$$
h(a)=0, \quad h^{\prime}(a)=\left[1-\frac{a}{x}\right]_{x=a}=0, \quad h^{\prime \prime}(a)=\frac{1}{a}>0,
$$


és $h^{\prime}(x) \neq 0(x \neq a)$, a $h$ függvény pozitív definit $x=a$ körül $x>0$ esetén. Ebból következik, hogy $V$ pozitív definit $\left(\lambda^{*}, C / \lambda^{*}\right)$ körül az $R$ halmazon.

A $\dot{V}_{(5.6)}$ deriváltra

$$
\begin{aligned}
\dot{V}(L, G) & =\left(L-\lambda^{*}\right) \dot{L}-C \frac{\dot{G}}{G}+\lambda^{*} \dot{G} \\
& =\left(L-\lambda^{*}\right)(C-L G)-\left(\frac{C}{G}-\lambda^{*}\right)\left(L-\lambda^{*}\right) G= \\
& =\left(L-\lambda^{*}\right)\left[C-L G-C+\lambda^{*} G\right]= \\
& =-\left(L-\lambda^{*}\right)^{2} G \leq 0 .
\end{aligned}
$$

Tetszóleges $(L(0), G(0)) \in Q$ pontra létezik olyan $\mu>0$, amelyre a $(L(0), G(0))$ pont a $V(L, G) \leq \mu$ szinthalmazban van, hiszen

$$
\lim _{G-\ln G \rightarrow \infty,|L| \rightarrow \infty} V(L, G)=\infty
$$

Mivel a Ljapunov-függvény deriváltja az (5.6) rendszer megoldásai mentén nem pozitív, az $(L(0), G(0))$ pontból indított megoldás minden $t>0$-ra a $V(L, G) \leq \mu$ szinthalmazon belül marad. A LaSalle-féle invarianciaelvból tudjuk, hogy a megoldás határhalmaza részhalmaza a $\dot{V}_{(5.6)}=0$ halmaznak, azaz a mi esetünkben az $L=\lambda^{*}$ egyenesnek. A $\left(\lambda^{*}, C / \lambda^{*}\right)$ egyensúlyi helyzet kivételével (5.6) megoldásai elmozdulnak az $L=\lambda^{*}$ egyenesról, így a határhalmaz az egyetlen pontból álló $\left\{\left(\lambda^{*}, C / \lambda^{*}\right)\right\}$ halmaz.

Amikor azt bizonyítjuk, hogy a $\left(\lambda^{*}, C / \lambda^{*}\right)$ pont eventuálisan stabil az eredeti nemautonóm (5.4) egyenletre nézve, szükségünk lesz az (5.3)-ban definiált $\lambda$ függvény következô tulajdonságára:

5.9. Lemma. Az (5.3)-ben definiált $\lambda$ függvény csökkenő és $\lambda^{*}$-hoz tart $(t \rightarrow$ $\infty)$.

Bizonyitás. Nyilvánvalóan

$$
\lambda(t)=-\frac{\dot{A}(t)}{A(t)}=\frac{\sum_{i=1}^{3} \lambda_{i} \mu_{i} e^{-\lambda_{i} t}}{\sum_{i=1}^{3} \mu_{i} e^{-\lambda_{i} t}}=\frac{\sum_{i=1}^{3} \lambda_{i} \mu_{i} e^{-\left(\lambda_{i}-\lambda^{*}\right) t}}{\sum_{i=1}^{3} \mu_{i} e^{-\left(\lambda_{i}-\lambda^{*}\right) t}} \rightarrow \lambda^{*} .
$$


Legyen $f:=-\dot{A}$ és $g:=A$, így $\lambda=f / g$, ahol $f$ és $g$ csökkenô, pozitív függvények. Differenciálással kapjuk, hogy

$$
\dot{\lambda}=\left(\frac{\dot{f}}{g}\right)=\frac{\dot{f} g-f \dot{g}}{g^{2}}
$$

Ellenôrizzük a számláló előjelét:

$$
\begin{aligned}
& \dot{f}(t) g(t)=-\sum_{i, j=1}^{3} \lambda_{i}^{2} \mu_{i} \mu_{j} e^{-\left(\lambda_{i}+\lambda_{j}\right) t}, \quad f(t) \dot{g}(t)=-\sum_{i, j=1}^{3} \lambda_{i} \lambda_{j} \mu_{i} \mu_{j} e^{-\left(\lambda_{i}+\lambda_{j}\right) t} \\
& \dot{f}(t) g(t)-f(t) \dot{g}(t)=-\sum_{i, j=1}^{3}\left(\lambda_{i}^{2}-\lambda_{i} \lambda_{j}\right) \mu_{i} \mu_{j} e^{-\left(\lambda_{i}+\lambda_{j}\right) t} \\
&=-\frac{1}{2} \sum_{i, j=1}^{3}\left(\lambda_{i}-\lambda_{j}\right)^{2} \mu_{i} \mu_{j} e^{-\left(\lambda_{i}+\lambda_{j}\right) t} \leq 0
\end{aligned}
$$

ami igazolja az állítást.

$\mathrm{Az}$ (5.8) függvény deriváltja nem jeltartó a nemautonóm (5.4) rendszer megoldásai mentén, tehát (5.8) erre a rendszerre nézve nem Ljapunov-függvény. Ennek ellenére - ahogy a következô állítás mutatja - „majdnem”-Ljapunovfüggvényként használható.

5.10. Lemma. Létezik olyan $M$ konstans, amelyre

$$
V(L(t), G(t)) \leq V(L(0), G(0))+M \quad(t \geq 0)
$$

teljesül (5.4) minden megoldására. Ezenkivül minden $\varepsilon>0$-ra létezik $\tau(\varepsilon) \geq$ 0 úgy, hogy ha $t_{0} \geq \tau(\varepsilon)$, akkor (5.4) minden megoldására teljesül a

$$
V(L(t), G(t)) \leq V\left(L\left(t_{0}\right), G\left(t_{0}\right)\right)+\varepsilon \quad\left(t \geq t_{0}\right)
$$

egyenlôtlenség. 
Bizonyitás. Az (5.8) Ljapunov-függvény (5.4) szerinti deriváltja

$$
\begin{aligned}
\dot{V}(L, G)_{(5.4)}= & \left(L-\lambda^{*}\right) \dot{L}-\dot{G} / G+\lambda^{*} \dot{G}= \\
= & \left(L-\lambda^{*}\right)(C-G L)-C(L-\lambda(t))+\lambda^{*}(L-\lambda(t)) G= \\
= & \left(L-\lambda^{*}\right)[C-G L-C]+C\left(\lambda(t)-\lambda^{*}\right) \\
& +\lambda^{*}\left[\left(L-\lambda^{*}\right)-\left(\lambda(t)-\lambda^{*}\right)\right] \\
= & \left(L-\lambda^{*}\right)\left(-G L+\lambda^{*} G\right)+C\left(\lambda(t)-\lambda^{*}\right)-\lambda^{*}\left(\lambda(t)-\lambda^{*}\right) G \\
= & -\left(L-\lambda^{*}\right)^{2} G+\left(\lambda(t)-\lambda^{*}\right)\left(C-\lambda^{*} G\right) \\
\leq & -\left(L-\lambda^{*}\right)^{2} G+\left(\lambda(t)-\lambda^{*}\right) C .
\end{aligned}
$$

Az elôzô becslést felhasználva kapjuk:

$$
\begin{aligned}
V(L(t), G(t))= & V(L(0), G(0))+\int_{0}^{t} \dot{V}(L(s), G(s)) d s \\
= & V(L(0), G(0))-\int_{0}^{t}(L(s)-\lambda(s))^{2} G(s) d s \\
& +\int_{0}^{t}\left(\lambda(s)-\lambda^{*}\right)(C-L(s) G(s)) d t \leq \\
\leq & V(L(0), G(0))+C \int_{0}^{t}\left(\lambda(s)-\lambda^{*}\right) d s \leq \\
\leq & V(L(0), G(0))+C \int_{0}^{\infty}\left(\lambda(s)-\lambda^{*}\right) d s .
\end{aligned}
$$

Mivel $\lambda(t) \searrow \lambda^{*}$ exponenciálisan $(t \rightarrow \infty)$, az utolsó becslésben szereplő integrál véges, ami igazolja a lemma elsô állítását.

Hasonlóan kapjuk, hogy

$$
\begin{aligned}
V(L(t), G(t)) & =V\left(L\left(t_{0}\right), G\left(t_{0}\right)\right)+\int_{t_{0}}^{t} \dot{V}(L(s), G(s)) d s \\
& \leq V\left(L\left(t_{0}\right), G\left(t_{0}\right)\right)+C \int_{t_{0}}^{\infty}\left(\lambda(s)-\lambda^{*}\right) d s
\end{aligned}
$$

Ebben az esetben az utolsó integrál tetszôlegesen kicsivé tehetô, ami igazolja a lemma második állítását. 
5.11. Lemma. $\left(\lambda^{*}, C / \lambda^{*}\right)$ eventuálisan egyenletesen stabil pontja a nemautonóm (5.4) rendszernek.

Bizonyítás. $\rho>0$-ra jelölje $C(\rho)$ és $D(\rho)$ a $\left(\lambda^{*}, C / \lambda^{*}\right)$ középpontú, $\rho$ sugarú körvonalat, illetve körlapot. Azt kell belátnunk, hogy tetszôleges $\varepsilon>0$-ra és $t_{0} \geq 0$-ra létezik $S(\varepsilon) \geq 0$ és $\delta(\varepsilon)>0$ úgy, hogy $t_{0} \geq S(\varepsilon)$ és $(L, G) \in D(\delta(\varepsilon))$ esetén $(L(t), G(t)) \in D(\varepsilon)$ minden $t \geq t_{0}$-ra.

Legyen $\varepsilon>0$ adott. Mivel (5.8) pozitív definit $\left(\lambda^{*}, C / \lambda^{*}\right)$ körül,

$$
m(\varepsilon):=\min \{V(L, G):(L, G) \in C(\varepsilon)\}>0
$$

teljesül és létezik $\delta(\varepsilon)>0$ úgy, hogy $V(L, G)<m(\varepsilon) / 2$, feltéve, hogy $(L, G) \in D(\delta(\varepsilon))$. Az 5.10. lemma szerint ha $t_{0} \geq \tau(m(\varepsilon) / 2)$ és $\left(L\left(t_{0}\right), G\left(t_{0}\right)\right) \in$ $D(\delta(\varepsilon))$, akkor

$$
V(L(t), G(t)) \leq V\left(L\left(t_{0}\right), G\left(t_{0}\right)\right)+\frac{m(\varepsilon)}{2}<m(\varepsilon),
$$

ahonnan $(L(t), G(t)) \in D(\varepsilon)$ adódik $t \geq t_{0}$-ra. Ez azt jelenti, hogy $S(\varepsilon):=$ $\tau(m(\varepsilon) / 2)$-vel és $\delta(\varepsilon)$-nal teljesül az eventuális egyenletes stabilitás definíciója.

5.12. Lemma. $\left(\lambda^{*}, C / \lambda^{*}\right)$ globálisan eventuálisan aszimptotikusan stabil pontja az eredeti nemautonóm (5.4) rendszernek.

Bizonyítás. Be kell látnunk, hogy (5.4) minden megoldása $\left(\lambda^{*}, C / \lambda^{*}\right)$-hoz tart $t \rightarrow \infty$ esetén. Tekintsük az (5.4) egyenlet egy tetszóleges $(L, G)$ megoldását. Az 5.10. lemma elsô állítása szerint a megoldás prekompakt, így pozitív határhalmaza, $\Lambda^{+}$nem üres. Megmutatjuk, hogy $\Lambda^{+}=\left\{\left(\lambda^{*}, C / \lambda^{*}\right)\right\}$.

Tegyük fel, hogy ez nem igaz, azaz létezik $\left(\lambda^{*}, C / \lambda^{*}\right)$-tól különböző $\left(L_{0}, G_{0}\right)$ pontja a határhalmaznak. Az 5.6. tétel szerint a $\Lambda^{+}$halmaz félig invariáns az (5.6) határegyenletre nézve. De $\left(\lambda^{*}, C / \lambda^{*}\right)$ globálisan aszimptotikusan stabil egyensúlyi helyzete az (5.6) egyenletnek, és $\Lambda^{+}$kompakt, így $\left(\lambda^{*}, C / \lambda^{*}\right) \in \Lambda^{+}$. 


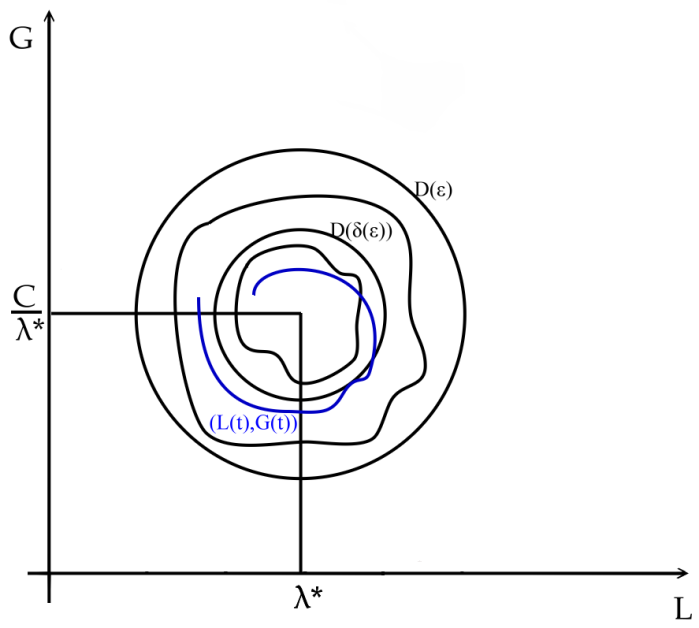

5.1. ábra. Eventuális egyenletes stabilitás

Legyen $\varepsilon_{0}>0$ olyan, hogy $\left(L_{0}, G_{0}\right) \notin D\left(\varepsilon_{0}\right)$ teljesül, és vegyük az $\varepsilon_{0} / 2$-höz az eventuális egyenletes stabilitás 5.1. definíciója szerint tartozó $S\left(\varepsilon_{0} / 2\right) \geq 0$, $\delta\left(\varepsilon_{0} / 2\right)>0$ számokat.

Mivel $\left(\lambda^{*}, C / \lambda^{*}\right) \in \Lambda^{+}$, az $\left(L\left(t_{*}\right), G\left(t_{*}\right)\right)$ pontnak $D\left(\delta\left(\varepsilon_{0} / 2\right)\right)$-be kell esnie valamely $t_{*}>S\left(\varepsilon_{0} / 2\right)$-re, és így $(L(t), G(t)) D\left(\varepsilon_{0} / 2\right)$-ben marad minden $t \geq t_{*}$-ra. Egyúttal viszont nagy $t$ értékekre $(L(t), G(t))$ tetszólegesen közel kerül $\left(L_{0}, G_{0}\right)$-hoz, ami ellentmondás (ld. 5.2. ábra).

\subsection{Az 5.5. tétel bizonyítása}

Vezessük be a

$$
d(L, G):=\sqrt{\left(L-\lambda^{*}\right)^{2}+\left(G-\frac{C}{\lambda^{*}}\right)^{2}}
$$

jelölést. Be kell látnunk, hogy a $\left(\lambda^{*}, C / \lambda^{*}\right)$ pont globálisan eventuálisan kváziegyenletesen aszimptotikusan stabil, vagyis azt, hogy minden $K>0$-ra és $\gamma>0$-ra létezik $S(K, \gamma) \geq 0$ és $T(K, \gamma)>0$ úgy, hogy $t_{0} \geq S(K, \gamma)$-ból és 


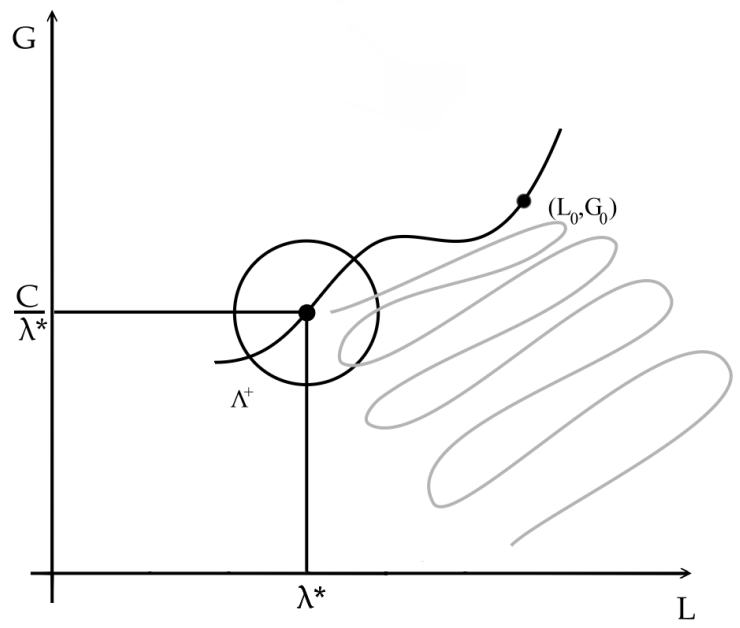

5.2. ábra. Trajektória és határhalmaza

$\left(1+\left|\ln G_{0}\right|\right) d\left(L_{0}, G_{0}\right) \leq K$-ból következik

$$
d\left(\left(L\left(t ; t_{0}, L_{0}, G_{0}\right), G\left(t ; t_{0}, L_{0}, G_{0}\right)\right)\right)<\gamma
$$

minden $t \geq t_{0}+T(K, \gamma)$-ra. Mivel az eventuális egyenletes stabilitást már beláttuk, (5.12) helyett elég igazolnunk, hogy létezik olyan $T_{*}=T_{*}(K, \gamma)>$ 0 , amelyre

$$
d\left(\left(L\left(t_{0}+T_{*} ; t_{0}, L_{0}, G_{0}\right), G\left(t_{0}+T_{*} ; t_{0}, L_{0}, G_{0}\right)\right)\right)<\delta(\gamma)
$$

teljesül, ahol $\delta(\gamma)$ a $\gamma$-hoz az eventuális egyenletes stabilitás szerint tartozó $\delta$ (ld. 5.1. definíció).

Tegyük fel, hogy ez nem teljesül, azaz létezik $\bar{K}>0$ és $\bar{\gamma}$ úgy, hogy minden $S \geq 0$-ra és $T>0$-ra létezik $t_{0} \geq S$ és olyan $\left(L_{0}, G_{0}\right)$, amelyre $\left(1+\left|\ln G_{0}\right|\right) d\left(L_{0}, G_{0}\right) \leq \bar{K}$ teljesül úgy, hogy

$$
d\left(\left(L\left(t ; t_{0}, L_{0}, G_{0}\right), G\left(t ; t_{0}, L_{0}, G_{0}\right)\right)\right) \geq \delta(\bar{\gamma}) \text { minden } t \in\left[t_{0}, t_{0}+T\right] \text {-re. }
$$


A következókben megoldások alatt csakis a fenti tulajdonsággal rendelkező megoldásokat értjük.

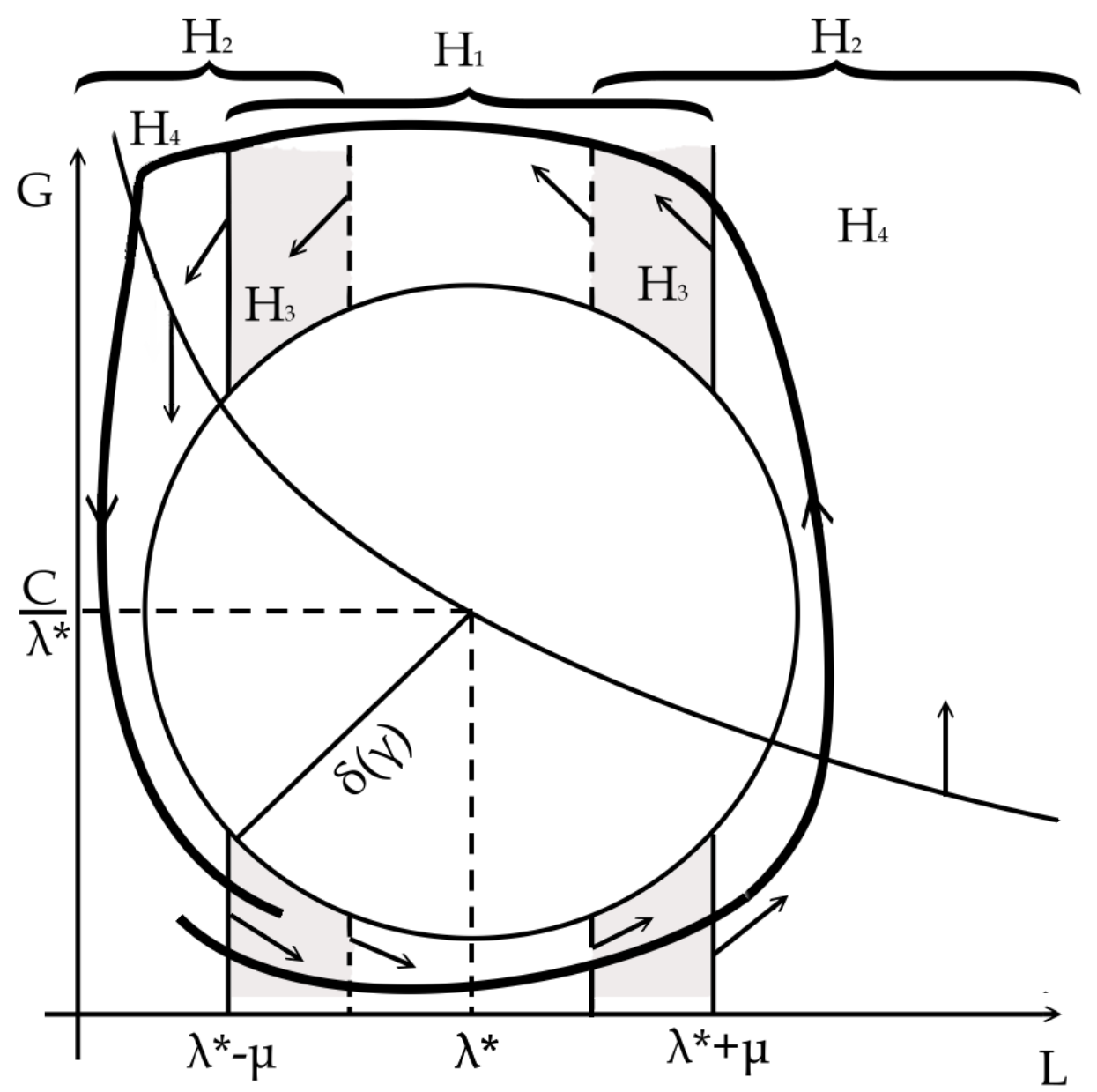

5.3. ábra. A $H_{1}, \ldots, H_{4}$ halmazok

Ahhoz, hogy ellentmondásra jussunk, az (5.8)-ban definiált Ljapunovfüggvényt fogjuk használni. Egyszerúen látható, hogy megadhatók olyan szigorúan monoton növekvô, 0-ban eltûnô $a, b:[0, \infty) \rightarrow(0, \infty)$ függvények, 
amelyekre

$$
a((1+|\ln G|) d(L, G)) \leq V(L, G) \leq b((1+|\ln G|) d(L, G))
$$

teljesül a felsô félsíkon. (5.4) tetszőleges megoldására vezessük be a

$$
v(t)=v\left(t ; t_{0}, L_{0}, G_{0}\right):=V\left(L\left(t ; t_{0}, L_{0}, G_{0}\right), G\left(t ; t_{0}, L_{0}, G_{0}\right)\right)
$$

jelölést. (5.15) és az 5.10. lemma szerint

$$
v(t) \leq b(\bar{K})+M \quad\left(t \geq t_{0}\right)
$$

teljesül (5.4) minden megoldására.

A $V$ függvény (5.4) szerinti deriváltja, (5.11) nem negatív definit, így megkülönböztetjük $Q$ részhalmazait aszerint, hogy $\dot{V}$ nagy vagy kicsi. Tetszôleges $\mu>0$-ra legyen

$$
\begin{array}{r}
H_{\leq}(\mu):=\{(L, G) \in Q: d(L, G) \geq \delta(\bar{\gamma}),(1+|\ln G|) d(L, G) \\
\left.\leq a^{-1}(b(\bar{K})+M),\left|L-\lambda^{*}\right| \leq \mu\right\}, \\
H_{\geq}(\mu):=\{(L, G) \in Q: d(L, G) \geq \delta(\bar{\gamma}),(1+|\ln G|) d(L, G) \\
\left.\leq a^{-1}(b(\bar{K})+M),\left|L-\lambda^{*}\right| \geq \mu\right\},
\end{array}
$$

és tekintsük a

$$
\begin{aligned}
& H_{1}(\mu):=H_{\leq}(\mu), \quad H_{2}(\mu):=H_{\geq}\left(\frac{\mu}{2}\right), \\
& H_{3}(\mu):=H_{\leq}(\mu) \cap H_{\geq}\left(\frac{\mu}{2}\right), H_{4}(\mu):=H_{\geq}(\mu)
\end{aligned}
$$

halmazokat (ld. az 5.3. ábrát).

A bizonyításnál felhasználjuk, hogy egy trajektória nem maradhat túl hosszú ideig a $H_{1}$ halmazban. Ennek igazolásához alulról becsüljük az $|\dot{L}|$ 
függvényt.

$$
\begin{aligned}
|\dot{L}| & =|C-G L|=\left|\lambda^{*}\left(\frac{C}{\lambda^{*}}-G\right)-G\left(L-\lambda^{*}\right)\right| \\
& \geq \lambda^{*}\left|\frac{C}{\lambda^{*}}-G\right|-\left|G\left(L-\lambda^{*}\right)\right| \\
& \geq \lambda^{*}\left|\frac{C}{\lambda^{*}}-G\right|-\left(\frac{C}{\lambda^{*}}+\delta(\bar{\gamma})\right) \mu>0
\end{aligned}
$$

elegendően kis $\mu$ esetén. Így létezik $\kappa_{1}>0$, amelyre

$$
|\dot{L}| \geq \kappa_{1}>0 \quad\left((L, G) \in H_{1}\right) .
$$

Amikor egy megoldás trajektóriája $H_{2}$-ben halad, a Ljapunov-függvény gyorsan csökken a megoldás mentén: (5.15)-ből kapjuk, hogy

$$
a^{-1}(b(\bar{K})+M) \geq(1+|\ln G|) d(L, G) \geq|\ln G| \delta(\bar{\gamma}),
$$

így

$$
G \geq \exp \left[-\frac{a^{-1}(b(\bar{K})+M)}{\delta(\bar{\gamma})}\right]
$$

(5.11)-ből a

$\dot{V}(L, G, t) \leq-\frac{\mu^{2}}{4} \exp \left[-\frac{a^{-1}(b(\bar{K})+M)}{\delta(\bar{\gamma})}\right]+C\left(\lambda(t)-\lambda^{*}\right) \quad\left((L, G) \in H_{2}, t \geq 0\right)$

becslést kapjuk, amiból következik, hogy létezik olyan $\bar{t}$ és $\kappa_{2}>0$, amelyre

$$
\dot{V}(L, G, t) \leq-\kappa_{2} \quad\left(t \geq \bar{t},(L, G) \in H_{2}\right)
$$

(5.15)-ból és az 5.10. lemmából következik, hogy minden megoldás trajektóriája prekompakt, így létezik $\kappa_{3}>0$, amelyre

$$
|\dot{L}(t)| \leq \kappa_{3} \quad\left(t \geq t_{0}\right)
$$

Adott $T>0$-ra és $t_{0} \geq \bar{t}$-re, tekintsünk egy $t \mapsto(L(t), G(t))$ megoldást, 
amely rendelkezik az (5.14) tulajdonsággal. Ekkor létezik egy

$$
t_{0} \leq s_{1}<t_{1}<s_{2}<\cdots<t_{n-1}<s_{n}<t_{n} \leq t_{0}+T
$$

sorozat úgy, hogy

$$
\begin{aligned}
& \text { ha } s_{i}<t<t_{i} \text {, akkor }(L(t), G(t)) \in H_{4} \quad(i=1,2, \ldots, n), \\
& \text { ha } t \in\left[t_{0}, t_{0}+T\right] \backslash\left(\cup_{i=1}^{n}\left[s_{i}, t_{i}\right]\right) \text {, akkor }(L(t), G(t)) \in H_{1} .
\end{aligned}
$$

A bizonyítás fennmaradó részének fő ötlete, hogy $v$ legalább egy konstanssal csökken minden $\left[s_{i}, t_{i}\right]$ intervallumon és $n=n(T) \rightarrow \infty$, amint $T \rightarrow \infty$. Mivel $v$ korlátos változású a $\left[t_{0}, \infty\right)$ intervallumon, ez azt jelenti, hogy $T$ nem lehet tetszólegesen nagy, ami ellentmond $\bar{K}, \bar{\gamma}$ létezésének. A bizonyítás befejezéséhez ezt az ötletet fejtjük ki részletesen.

Mivel $H_{4} \subset H_{2}$, (5.15)-ból, az 5.10. lemmából és (5.18)-ból kapjuk, hogy

$$
\sum_{i=1}^{n}\left(t_{i}-s_{i}\right) \leq \frac{b(\bar{K})+M}{\kappa_{2}}=: \bar{T}
$$

Ezenkívül (5.17)-ból és (5.19)-bôl adódik, hogy $s_{i}-t_{i-1} \leq 2 \mu / \kappa_{1}$ minden $i=2,3, \ldots, n$-re. A két legutóbbi becslésből következik, hogy

$$
n=n(T) \geq \frac{T-\bar{T}}{\frac{2 \mu}{\kappa_{1}}} \rightarrow \infty \quad(T \rightarrow \infty) .
$$

Másrészt, az

$$
[x]_{+}:=\max \{x, 0\}, \quad[x]_{-}:=\max \{-x, 0\}, \quad(x \in \mathbb{R}),
$$

jelöléseket használva

$$
\begin{aligned}
-\int_{t_{0}}^{t_{0}+T}[\dot{v}(t)]_{-} d t & \leq-\sum_{i=2}^{n} \int_{t_{i-1}}^{s_{i}}[\dot{v}(t)]_{-} d t \leq \int_{(L(t), G(t)) \in H_{3}} \dot{v}(t) d t \\
& \leq-2(n-2) \kappa_{2} \frac{\mu}{2 \kappa_{3}}
\end{aligned}
$$


Ebból következik, hogy

$$
\begin{aligned}
-b(\bar{K})-M & \leq v\left(t_{0}+T\right)-v\left(t_{0}\right)=\int_{t_{0}}^{t_{0}+T}\left([\dot{v}(t)]_{+}-[\dot{v}(t)]_{-}\right) d t \\
& \leq M-2(n-2) \kappa_{2} \frac{\mu}{\kappa_{3}} \rightarrow-\infty \quad(T \rightarrow \infty) .
\end{aligned}
$$

Ez azt jelenti, hogy $T$ nem lehet tetszőlegesen nagy, ami ellentmond $\bar{K}, \bar{\gamma}$ létezésének. Ez az ellentmondás bizonyítja az 5.5. tételt.

5.13. Megjegyzés. Thieme [20] kidolgozott egy módszert, amely elegendô feltételeket ad arra, hogy az eredeti aszimptotikusan autonóm rendszer megoldásainak aszimptotikus viselkedése megyezzen a határegyenlet megoldásainak aszimptotikus viselkedésével.

Castillo-Chávez és Thieme megadta e módszer egy következményét [4, 2.2. következmény], amely a mi esetünkben is alkalmazható, és biztosítja azt, hogy (5.4) minden korlátos megoldása az (5.6) rendszer egy egyensúlyi helyzetéhez tartson $t \rightarrow \infty$ esetén. Más szóval, az 5.12. lemma állítása következik az 5.10. lemmából és ebból a következményből. A dolgozatban mégis megadtuk az 5.12. lemma egy közvetlen bizonyítását annak érdekében, hogy a dolgozat a fenti következmény ismerete nélkül is olvasható legyen.

$\mathrm{Az}$ 5.5. tétel bizonyításának fô ötlete, hogy az (5.6) határegyenlethez tartozó Ljapunov-függvényt használjuk az eredeti aszimptotikusan autonóm (5.4) egyenlet stabilitási tulajdonságainak igazolásához. Ezt a módszert Yoshizawa [23] és LaSalle [16] vezette be, késôbb Artstein [1] fejlesztette tovább. Például az 5.10. lemmából és [1] 8.3. tételéból következik, hogy (5.4) minden megoldása tart az $\left\{L=\lambda^{*}\right\}$ egyeneshez.

Fontos azonban hangsúlyozni azt, hogy a felsorolt eredmények nem használhatók a $\left(\lambda^{*}, C / \lambda^{*}\right)$ pont eventuális egyenletes stabilitási tulajdonságainak igazolására. 


\subsection{A modell módosítása}

A fentiekben leírt rendszer nem az egyetlen lehetôség az 5.1. szakaszban bemutatott populáció modellezésére. Biológiailag különösen érdekes az az eset, amikor a növényzet magára hagyva exponenciális törvény szerint szaporodna. A növényzet fejlődésére vonatkozó egyenlet így a következô:

$$
\dot{K}=\left(C-\sum_{i} n_{i} \alpha\left(w_{i}\right)\right) K
$$

Az 5.2. szakaszban ismertetett egyszerúsítéshez hasonlóan a rendszer az

$$
\begin{aligned}
\dot{L} & =(C-G) L \\
\dot{G} & =(L-\lambda(t)) G
\end{aligned}
$$

alakra hozható, így egy aszimptotikusan autonóm Lotka-Volterra-egyenlethez jutunk, melynek vizsgálatán jelenleg is dolgozunk. A számítógépes vizsgála-

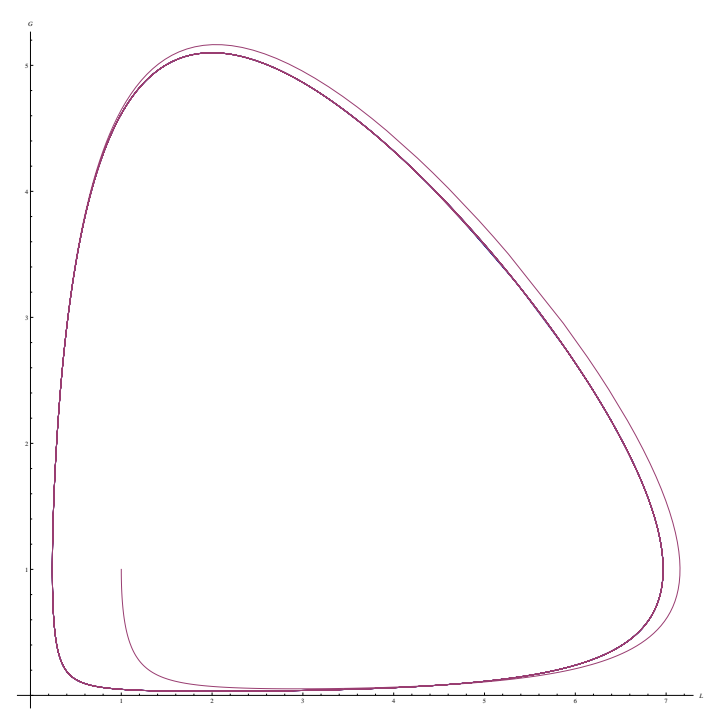

5.4. ábra. (5.22) egy pályájának képe Mathematicá-val

tok azt sugallják, hogy itt a határpont helyett egy határciklus jelenik meg 
(ld. 5.4. ábra). Az (5.22) rendszer határegyenlete, a

$$
\begin{aligned}
\dot{L} & =(C-G) L, \\
\dot{G} & =\left(L-\lambda^{*}\right) G
\end{aligned}
$$

rendszer a klasszikus Lotka-Volterra-egyenlet [2] egy speciális esete, így megoldásai a $W(L, G)=G^{C} L^{\lambda} e^{-(G+L)}$ függvény szintvonalai. Sejtésünk az, hogy az (5.22) egyenlet minden megoldásának határhalmaza a $W(x, y)$ függvény egy-egy szintvonala, azaz a határegyenlet egy-egy megoldása. 


\section{Összefoglalás}

A disszertáció három különbözô problémával foglalkozik: két populációdinamikai modellel és egy, a dinamikus rendszerek attraktorait, illetve azok medencéit meghatározó és megjelenítő algoritmussal, illetve az az alapján készült programmal.

Az értekezés a szerzô következô publikációin alapul:

- Dénes, A., Neimark-Sacker bifurcation in a discrete dynamical model of population genetics, Electronic Journal of Qualitative Theory of Differential Equations, Proc. 8th Coll. Qualitative Theory of Diff. Equ., No. 6. (2008), 1-10.

- Dénes, A., Hatvani, L., Stachó, L. L., Eventual stability properties in a non-autonomous model of population dynamics, Nonlinear Analysis 73 (2010) 650-659.

- Dénes, A., Makay, G., Attractors and basins of dynamical systems, Electronic Journal of Qualitative Theory of Differential Equations, No. 20. (2011), 1-11.

A disszertáció 2. fejezetében a dinamikus rendszerekkel kapcsolatos legfontosabb alapfogalmakat definiáljuk.

A 3. fejezetben Tusnády Gábor egy diszkrét populációdinamikai modelljét vizsgáljuk. Ez a négydimenziós nemlineáris differenciaegyenlet-rendszer az ivarsejtek eloszlásának változását írja le egy populációban egy lókusz és négy allél esetén a szelekció és a mutáció hatásának figyelembevételével. Tusnády Gábor számítógépes kísérletezéssel talált olyan eseteket, amelyekben a 
rendszer attraktora nem egy pont (vagyis az eloszlások között nem áll be dinamikus egyensúly), hanem periodikus pálya, sôt, valamilyen kaotikus halmaz. Tusnády Gábor azt kérdezte, hogy törvényszerû-e ez a jelenség, vagy esetleg csak a numerikus közelítés hibájából adódik. A rendszert először a 4. fejezetben ismertetett attraktorszámító program segítségével vizsgáltuk. Az egyik paraméter értékének változtatásakor kapott ábrák szuperkritikus NeimarkSacker-bifurkációra utalnak: a rendszer stabil fixpontjából zárt görbe keletkezik, míg a fixpont instabillá válik. A fejezet fố eredményében, a 3.5. tételben belátjuk, hogy a rendszer valóban Neimark-Sacker-bifurkáción megy keresztül. Egy adott $p$ paraméter értékének változtatásával a Jacobi-mátrix komplex sajátértékpárja áthalad a komplex sík origó körüli egységkörén. Ennek a komplex sajátértékpárnak megfelel a fixpont kétdimenziós instabil sokasága. Az invariáns zárt görbe ezen az instabil sokaságon jelenik meg. Annak igazolásához, hogy e paraméterértéknél bifurkáció történik, be kell látnunk, hogy a rendszer teljesít bizonyos nemelfajulási feltételeket. [14] alapján ismertetjük az eljárást, amellyel igazolhatjuk a rendszer nemelfajulását. Elôször kétdimenziós rendszerekre mondjuk ki az általános Neimark-Sacker-bifurkációról szóló tételt. Magasabb dimenziós rendszereknél lényegében ugyanaz történik, mint két dimenzióban: létezik egy kétdimenziós invariáns sokaság, amelyen a rendszer bifurkáción megy át, a sokaságon kívül pedig a rendszer viselkedése „triviális”, mert ott nincs bifurkáció. A disszertációban ismertetünk egy módszert, amelynek segítségével - a Jacobi-mátrix és transzponáltja sajátértékeit felhasználva - a rendszert levetíthetjük a kritikus sajátaltérbe. Végül az eljárás lépéseit követve belátjuk a 3.5. tétel állítását.

A 4. fejezetben egy új, dinamikus rendszerek attraktorainak és azok medencéinek ábrázolására szolgáló algoritmust írunk le, amely a korábbiaknál pontosabb számítások alapján múködik. Új algoritmusunk a Dynamics programcsomag Basins and Attractors eljárásának továbbfejlesztése, ezért elsôként ezt az eljárást mutatjuk be, majd ismertetjük az új algoritmust és az algoritmus alapján készült programot.

Az algoritmus alapelve a következô: a vizsgált $n$ dimenziós térrészt felosztjuk egyenlő nagyságú $n$ dimenziós téglatestekre, és mindegyik közepébôl elin- 
dítunk egy trajektóriát. Minden lépésben megvizsgáljuk az aktuális ponthoz közel eső pontokat (vagyis azon pontokat, amelyek az aktuális ponttal azonos vagy szomszédos téglatestbe esnek), és amennyiben találunk olyan trajektóriát, amellyel aktuális pályánk bizonyos számú lépésen keresztül együtt halad (azaz megfelelô pontjaik azonos vagy szomszédos téglatestekbe esnek), akkor színt adunk a vizsgált pályának: ha egy korábbi trajektóriába ütköztünk, akkor annak a színét kapja az aktuális trajektória is, ha pedig önmagába ütközött, akkor új, addig nem használt színt kap a pálya. Eltároljuk, hogy melyik volt az a pont, amelyikhez először visszatértünk: ettől a ponttól kezdve fogjuk a trajektória pontjait az attraktor színével színezni.

A fejezet végén néhány híres diszkrét dinamikus rendszer attraktorait bemutató ábrával szemléltetjük a program múködését, és egy nevezetes példával illusztráljuk, hogy algoritmusunk olyan esetekben is pontos attraktorokat és medencéket tud rajzolni, amelyekben a korábbi algoritmusok pontatlan képeket szolgáltattak.

Djellit és Boukemara $[8]$ az

$$
\begin{aligned}
& x_{1}^{\prime}=x_{1}+1,0025 x_{2}+1,44 x_{1}\left(x_{1}-1\right)-0,1 x_{1} x_{2} \\
& x_{2}^{\prime}=1,0025 x_{2}+1,44 x_{1}\left(x_{1}-1\right)-0,1 x_{1} x_{2}
\end{aligned}
$$

Bogdanov-leképezés attraktorait és medencéit pontatlanul adták meg, és erre a rendszerre a Dynamics is pontatlan ábrát ad (4.3. ábra). A programunk által készített rajz (4.2. ábra) pontosan mutatja az attraktorokat és medencéiket: az origó körüli öt világoszöld pontból álló attraktor medencéje a Dynamics ábrája szerint egy öt szigetből álló halmaz, valójában azonban ahogy azt a programunk által készített ábra mutatja - a szigetek által közrefogott részben is sưrú az attraktor medencéje. E terület a Dynamics rajzán az öt pontból álló attraktor körüli zöld zárt görbe medencéjéhez tartozik.

Az 5. fejezet egy populációdinamikai rendszerrel foglalkozik, amely a Tanganyika-tóban éló két halfaj (egy növényevó és egy ragadozó), valamint a növényevốk táplálékául szolgáló növények mennyiségének változását írja le. A modell két részből áll: év közben egy differenciálegyenlet-rendszer írja le a 
fejlődést, míg minden év végén egy diszkrét dinamikus rendszer írja le a halak szaporodását. Az év közbeni fejlődést leíró nemautonóm differenciálegyenletrendszer - egyszerúsítések után - a következô alakú:

$$
\begin{aligned}
\dot{L} & =C-L G, \\
\dot{G} & =(L-\lambda(t)) G,
\end{aligned}
$$

ahol $\lambda:(0, \infty) \rightarrow(0, \infty)$ adott folytonos függvény, $\lim _{t \rightarrow \infty} \lambda(t)=\lambda^{*}>0$ létezik. A fenti rendszernek nincs egyensúlyi helyzete, az

$$
\begin{aligned}
\dot{L} & =C-L G, \\
\dot{G} & =\left(L-\lambda^{*}\right) G
\end{aligned}
$$

határegyenletnek viszont a $\left(\lambda^{*}, C / \lambda^{*}\right)$ pont egyensúlyi helyzete. Ilyen esetben az ún. eventuális stabilitási tulajdonságokat szokták vizsgálni. Fô eredményünk a következő:

5.5. Tétel. $\left(\lambda^{*}, C / \lambda^{*}\right)$ globálisan eventuálisan egyenletesen aszimptotikusan stabil pontja a fenti rendszernek.

Röviden szólva ez azt jelenti, hogy a fázissík bármely pontjából indított megoldás tart a $\left(\lambda^{*}, C / \lambda^{*}\right)$ ponthoz, éspedig bizonyos értelemben egyenletesen a kiindulási állapotokra nézve.

Az 5.5. tétel bizonyításához a következô lemmákon keresztül jutunk:

5.7. Lemma. Az (5.6) határegyenlet $\left(\lambda^{*}, C / \lambda^{*}\right)$ egyensúlyi helyzete aszimptotikusan stabil.

Először linearizáljuk a rendszert a (lokális) aszimptotikus stabilitás igazolásához, majd megkonstruáljuk a

$$
V(L, G)=\frac{1}{2}\left(L-\lambda^{*}\right)^{2}-C \ln G+\lambda^{*} G-C+C \ln \frac{C}{\lambda^{*}}
$$

Ljapunov-függvényt, és a LaSalle-féle invarianciaelv alkalmazásával igazoljuk, hogy az egyensúlyi helyzet globálisan aszimptotikusan stabil.

5.8. Lemma. $A z(5.6)$ határegyenlet $\left(\lambda^{*}, C / \lambda^{*}\right)$ egyensúlyi helyzete globálisan 
aszimptotikusan stabil a $Q:=\{(L, G): L \geq 0, G>0\}$ siknegyedben.

5.10. Lemma. Létezik olyan $M$ konstans, amelyre

$$
V(L(t), G(t)) \leq V(L(0), G(0))+M \quad(t \geq 0)
$$

teljesül (5.4) minden megoldására. Ezenkívül minden $\varepsilon>0$-ra létezik $\tau(\varepsilon) \geq 0$ úgy, hogy ha $t_{0} \geq \tau(\varepsilon)$, akkor (5.4) minden megoldására teljesül a

$$
V(L(t), G(t)) \leq V\left(L\left(t_{0}\right), G\left(t_{0}\right)\right)+\varepsilon \quad\left(t \geq t_{0}\right)
$$

egyenlótlenség.

5.11. Lemma. $\left(\lambda^{*}, C / \lambda^{*}\right)$ eventuálisan egyenletesen stabil pontja a nemautonóm (5.4) rendszernek.

5.12. Lemma. $\left(\lambda^{*}, C / \lambda^{*}\right)$ globálisan eventuálisan aszimptotikusan stabil pontja az eredeti nemautonóm (5.4) rendszernek. 


\section{Summary}

The thesis investigates three different problems: two population dynamical models and an algorithm for calculating and representing attractors and basins of dynamical systems as well as a computer program based on this algorithm.

The dissertation is based on the following papers of the author:

- Dénes, A., Neimark-Sacker bifurcation in a discrete dynamical model of population genetics, Electronic Journal of Qualitative Theory of Differential Equations, Proc. 8th Coll. Qualitative Theory of Diff. Equ., No. 6. (2008), 1-10.

- Dénes, A., Hatvani, L., Stachó, L. L., Eventual stability properties in a non-autonomous model of population dynamics, Nonlinear Analysis 73 (2010) 650-659.

- Dénes, A., Makay, G., Attractors and basins of dynamical systems, Electronic Journal of Qualitative Theory of Differential Equations, No. 20. (2011), 1-11.

In the second chapter of the thesis we define some of the most important basic concepts from the theory of dynamical systems.

In Chapter 3 we investigate a population dynamical model initiated by Gábor Tusnády. This four-dimensional nonlinear system of difference equations describes the change of distribution of gametes in a population in the case of one locus and four alleles considering selection and mutation. During 
computer experiments Gábor Tusnády found parameter values with which the attractor of the system was not one point (i.e. no dynamical equilibrium arises amongst the distributions), but a periodic orbit, or even a chaotic set. Gábor Tusnády asked whether this phenomenon could be established mathematically or it was just caused by the errors of numerical approximation. First we used the program for calculating attractors described in Chapter 4 to examine the system. The figures we obtained changing one of the parameters imply the presence of a supercritical Neimark-Sacker bifurcation: a closed curve arises from the stable fixed point of the system, while the fixed point becomes unstable. In the main result of the section, Theorem 3.5, we show that the system indeed undergoes a Neimark-Sacker-bifurcation. When we change the value of a given parameter, a complex pair of eigenvalues of the Jacobian passes through the unit circle. To this complex pair of eigenvalues corresponds a two-dimensional unstable manifold of the fixed point. The invariant closed curve appears on this manifold. To prove that a bifurcation occurs at this parameter value we have to verify that the system satisfies some genericity conditions. Using monograph [14] we delineate the procedure that we can use to prove the nondegenericity of the system. First we formulate the Neimark-Sacker bifurcation theorem for two-dimensional systems. In the case of systems with dimension higher than 2 essentially the same takes place: there exists a two-dimensional invariant manifold on which the system exhibits the bifurcation, while the behaviour off the manifold is "trivial", as no bifurcation occurs there. In the thesis we delineate a method with the help of which - using the eigenvalues of the Jacobian and its transpose - we can "project" the system into the critical eigenspace. Finally, following the steps of the procedure we prove Theorem 3.5.

In Chapter 4 we describe a new algorithm for representing attractors and basins of dynamical systems which calculates more precisely then the previous similar algorithms. Our new algorithm is an improvement of the procedure Basins and Attractors of Dynamics, that is why we present this procedure first, then we delineate the new algorithm and the program realizing the algorithm. 
The principle of the algorithm is the following: we divide the $n$-dimensional domain under examination into equal $n$-dimensional boxes and from the center of each box we start a trajectory. In each step we examine the points near to our actual point (i.e. the points that fall into the same grid box or neighbouring grid boxes), and if we find a trajectory such that its iterates remain near to the iterates of our actual point for a given number of steps (i.e. the corresponding points fall into the same grid box or neighbouring grid boxes), we give a colour to the trajectory: if we have encountered a previous trajectory, then we give its colour to the actual trajectory; if the trajectory encountered itself, then it is given a new, previously not used colour. We save the point to which we returned first: from this point on we colour the points of the trajectory with the colour of the attractor.

At the end of the chapter we demonstrate the use of the program with figures representing the attractors of some well-known discrete dynamical systems and we give an example to show that our algorithm is able to draw precise attractors and basins even in cases where previous algorithms provide an imprecise picture.

Djellit and Boukemara [8] have given imprecisely the attractors and basins of the Bogdanov map

$$
\begin{aligned}
& x_{1}^{\prime}=x_{1}+1.0025 x_{2}+1.44 x_{1}\left(x_{1}-1\right)-0.1 x_{1} x_{2} \\
& x_{2}^{\prime}=1.0025 x_{2}+1.44 x_{1}\left(x_{1}-1\right)-0.1 x_{1} x_{2},
\end{aligned}
$$

and also Dynamics gives an imprecise picture for this system (Figure 4.3). The figure made by or program (Figure 4.2) shows the attractors and their basins precisely: according to the figure made by Dynamics the basin of the attractor formed by five light green points around the origin consists of five islands around the five points, however - as it is shown on the figure made by our program - this basin is also dense in the area inside the five islands. In the figure of Dynamics this area belongs to the basin of the green closed curve around the five points.

Chapter 5 deals with a population dynamical system which describes the 
change of the amount of two fish species (a carnivore and a herbivore) living in Lake Tanganyika and the amount of the plants eaten by the herbivores. The model consists of two parts: the development during one year is described by a system of differential equations, while the reproduction of the fish at the end of each year is described by a discrete dynamical system. The non-autonomous system of differential equations describing the development during the year - after a series of transformations - has the following form:

$$
\begin{aligned}
\dot{L} & =C-L G, \\
\dot{G} & =(L-\lambda(t)) G
\end{aligned}
$$

where $\lambda:(0, \infty) \rightarrow(0, \infty)$ is a given continuous function and $\lim _{t \rightarrow \infty} \lambda(t)=$ $\lambda^{*}>0$. This system does not have an equilibrium, but its limit equation

$$
\begin{aligned}
\dot{L} & =C-L G, \\
\dot{G} & =\left(L-\lambda^{*}\right) G
\end{aligned}
$$

has the fixed point $\left(\lambda^{*}, C / \lambda^{*}\right)$. In such cases usually the so-called eventual stability properties are studied. Our main result is the following:

Theorem 5.5. The point $\left(\lambda^{*}, C / \lambda^{*}\right)$ is an eventually uniform-asymptotically stable point of (5.4).

In short this means that a solution started from any point of the phase space tends to the point $\left(\lambda^{*}, C / \lambda^{*}\right)$ in some sense uniformly.

The proof of Theorem 5.5 is obtained through the following lemmas:

Lemma 5.7. The equilibrium point $\left(\lambda^{*}, C / \lambda^{*}\right)$ of the limit equation (5.6) is asymptotically stable.

First we linearize the system to prove (local) asymptotic stability, then we construct the Lyapunov function

$$
V(L, G)=\frac{1}{2}\left(L-\lambda^{*}\right)^{2}-C \ln G+\lambda^{*} G-C+C \ln \frac{C}{\lambda^{*}}
$$

and using LaSalle's invariance principle we prove that the equilibrium is 
globally asymptotically stable.

Lemma 5.8. The equilibrium point $\left(\lambda^{*}, C / \lambda^{*}\right)$ of the limit equation (5.6) is asymptotically stable in the large on quadrant $Q:=\{(L, G): L \geq 0, G>0\}$.

Lemma 5.10. There is a constant $M$ such that

$$
V(L(t), G(t)) \leq V(L(0), G(0))+M \quad(t \geq 0)
$$

holds for all solutions of (5.4). Moreover, for every $\varepsilon>0$ there exists a $\tau(\varepsilon) \geq 0$ such that if $t_{0} \geq \tau(\varepsilon)$ then every solution of (5.4) satisfies the inequality

$$
V(L(t), G(t)) \leq V\left(L\left(t_{0}\right), G\left(t_{0}\right)\right)+\varepsilon \quad\left(t \geq t_{0}\right) .
$$

Lemma 5.11. $\left(\lambda^{*}, C / \lambda^{*}\right)$ is an eventually uniformly stable point of the nonautonomous system (5.4).

Lemma 5.12. $\left(\lambda^{*}, C / \lambda^{*}\right)$ is an eventually asymptotically stable point of the original non-autonomous system (5.4) in the large. 


\section{Köszönetnyilvánítás}

Szeretnék köszönetet mondani témavezetőmnek, Dr. Hatvani László professzor úrnak, akinek hatására és tanácsára másodéves koromban differenciálegyenletekkel kezdtem foglalkozni. Ezúton is szeretném megköszönni azt a sok segítséget és értékes tanácsot, amit az elmúlt években kutatómunkám során, illetve a disszertáció elkészítéséhez tôle kaptam. Nagy megtiszteltetés számomra, hogy doktoranduszként az ô irányításával dolgozhattam.

Köszönettel tartozom társszerzóimnek, Dr. Makay Géza docens úrnak és Dr. Stachó László docens úrnak. Nagy öröm és megtiszteltetés volt együtt dolgozni velük az általuk felvetett érdekes problémákon.

Szeretnék köszönetet mondani Dr. Krisztin Tibor professzor úrnak a tudományos tevékenységemhez nyújtott támogatásáért.

Köszönetet mondok Dr. Karsai János docens úrnak a tôle kapott segítségért, a cikkek megírásához nyújtott hasznos tanácsaiért.

A dolgozat elkészítése során az OTKA K75517 pályázata és a TÁMOP4.2.2/08/1/2008-0008 pályázat támogatott. 


\section{Tárgymutató}

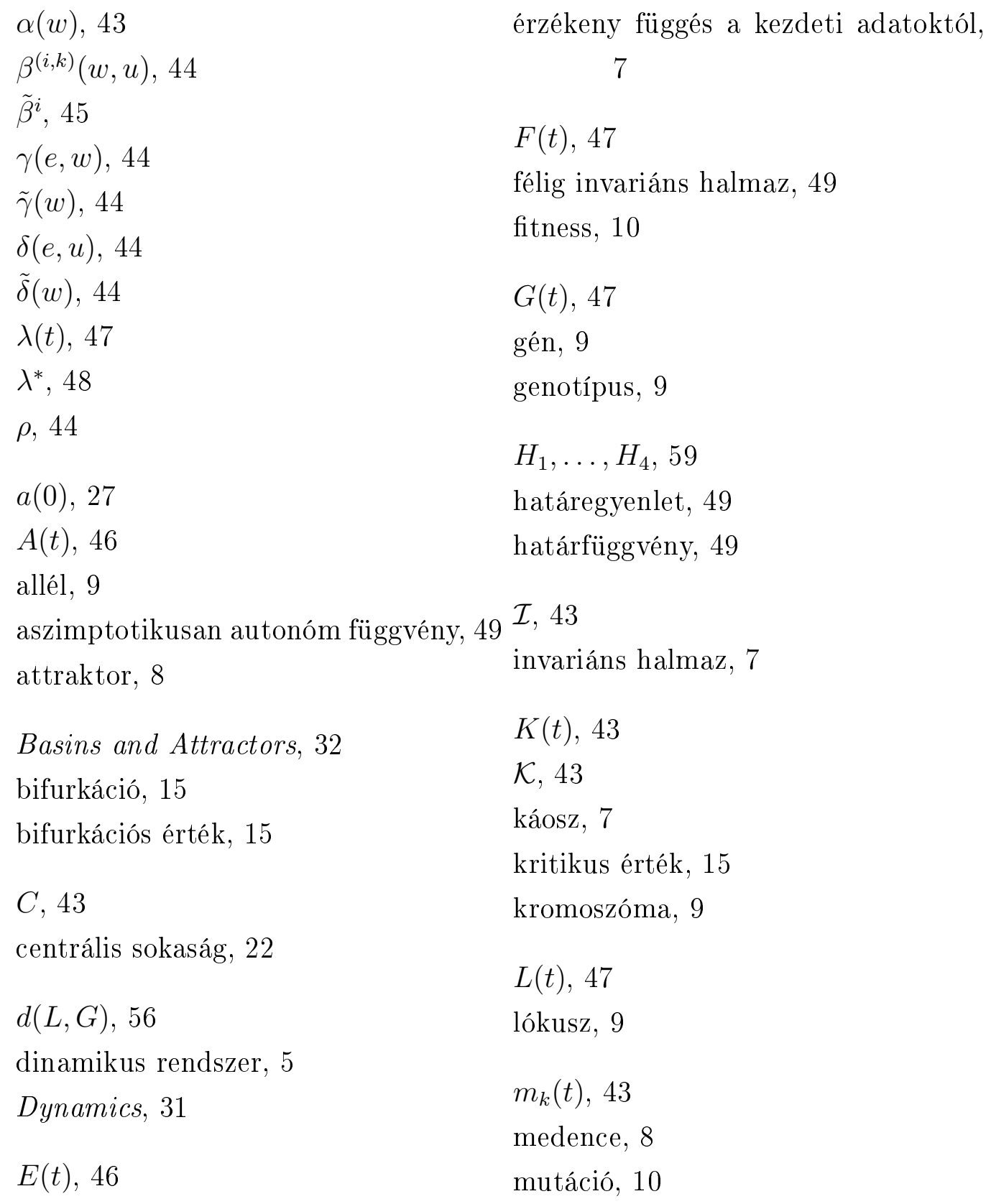


Neimark-Sacker-bifurkáció, 15

pozitív határhalmaz, 49

pozitív határpont, 49

$Q, 47$

rekombináció, 11

stabilitás

eventuális, 48

globális eventuális aszimptotikus,

48

globális eventuális egyenletes aszimptotikus, 49

globális eventuális kvázi-egyenletes aszimptotikus, 48

szelekció, 10

topologikus ekvivalencia, 15

topologikus tranzitivitás, 7

Tusnády-modell, 12

$u_{k}(t), 43$

$v(t), 59$

$V(L, G), 51$

$w_{i}(t), 43$

$W(L, G), 64$

$x_{i}(t), 45$

$y_{k}(t), 45$ 


\section{Irodalomjegyzék}

[1] Artstein, Z., Limiting equations and stability of non-autonomous ordinary differential equations, Appendix to J. P. LaSalle, The Stability of Dynamical Systems, Regional Conference Series in Applied Mathematics, vol. 25, SIAM, Philadelphia, 1976.

[2] Bacaër, N., A Short History of Mathematical Population Dynamics, Springer-Verlag, London, 2011.

[3] Brauer, F., Castillo-Chávez, C., Mathematical Models in Population Biology and Epidemiology, Springer-Verlag, New York, 2001.

[4] Castillo-Chavez, C., Thieme, H. R., Asymptotically autonomous epidemic models, in: O. Arino, D. Axelrod, M. Kimmel and M. Langlais (Eds.), Mathematical Population Dynamics: Analysis and Heterogeneity, vol. 1: Theory of Epidemics, Wuerz Publishing Ltd., Winnipeg, Canada, 1995, pp. 33-50.

[5] Dénes, A., Neimark-Sacker bifurcation in a discrete dynamical model of population genetics, Electronic Journal of Qualitative Theory of Differential Equations, Proc. 8th Coll. Qualitative Theory of Diff. Equ., No. 6. (2008), 1-10.

[6] Dénes, A., Hatvani, L., Stachó, L. L., Eventual stability properties in a non-autonomous model of population dynamics, Nonlinear Analysis $\mathbf{7 3}$ (2010) 650-659. 
[7] Dénes, A., Makay, G., Attractors and basins of dynamical systems, Electronic Journal of Qualitative Theory of Differential Equations, No. 20. (2011), 1-11.

[8] Djellit, I., Boukemara, I., Bifurcations and Attractors in Bogdanov Map, Vis. Math. 6, No. 4 (2004)

[9] Hofbauer, S., Sigmund, K., Evolutionary Games and Population Dynamics, Cambridge University Press, 1998.

[10] Hoppensteadt, F. C., Peskin, C. S., Mathematics in Medicine and the Life Sciences, Springer-Verlag, New York, 1992.

[11] Hatvani, L., Toókos, F., Tusnády, G., A mutation-selectionrecombination model in population genetics, Dynam. Systems Appl. 8 (2009), No. 2, 335-361.

[12] Koçak, H., Differential and difference equations through computer experiments, Springer-Verlag, 1989.

[13] Kulenović, M. R. S., Merino, O., Discrete Dynamical Systems and Difference Equations with Mathematica, Chapman \& Hall/CRC, 2002.

[14] Kuznetsov, Y. A., Elements of applied bifurcation theory, SpringerVerlag, 1998.

[15] Lakshmikantham, V., Leela, S., Differential and Integral Inequalities, vol. I, Mathematics in Science and Engineering, vol. 55-I, Academic Press, New York, 1969.

[16] LaSalle, J. P., Stability theory for ordinary differential equations, $J$. Differential Equations, 4 (1968) 57-65.

[17] Mboko, S. K., Kohda, M., Hori, M., Asymmetry of mouth-opening of a small herbivorous cichlid fish Telmatochromis temporalis in lake Tanganyika, Zoological Science, 15 (1998) 405-408. 
[18] Nusse, H. E., Yorke, J. A., Dynamics: Numerical Explorations, SpringerVerlag, 1998.

[19] Rouche, N., Habets, P., Laloy, M., Stability Theory by Liapunov's Direct Method, Applied Mathematical Sciences, vol. 22, Springer-Verlag, New York-Heidelberg, 1977.

[20] Thieme, H. R., Asymptotically autonomous differential equations in the plane, 20th Midwest ODE Meeting (Iowa City, IA, 1991), Rocky Mountain J. Math. 24 (1994) 351-380.

[21] Tusnády G., Mutáció és szelekció, Magyar Tudomány 42 (1997), 792805.

[22] Yoshizawa, T., Stability Theory by Liapunov's Second Method, The Mathematical Society of Japan, Tokyo, 1966.

[23] Yoshizawa, T., Asymptotic behavior of solutions of a system of differential equations, Contributions to Differential Equations, 1 (1963) 371-387.

[24] Wiggins, S., Introduction to Applied Nonlinear Dynamical Systems and Chaos, Springer-Verlag, New York, 2003. 